\title{
Late Neoproterozoic and Early Cambrian palaeogeography: models and problems
}

\author{
Sergei A. Pisarevsky ${ }^{1}$, J. Brendan Murphy², Peter A. Cawood ${ }^{1}$, Alan S. Collins ${ }^{3}$ \\ ${ }^{1}$ Tectonics Special Research Centre, School of Earth and Geographical Sciences, The \\ University of Western Australia, 35 Stirling Highway, Crawley, 6009, WA, Australia \\ (e-mail: spisarevsky@tsrc.uwa.edu.au) \\ ${ }^{2}$ Deptartment of Earth Sciences St. Francis Xavier University, Antigonish, Nova Scotia, \\ B2G 2W, Canada \\ ${ }^{3}$ Continental Evolution Research Group, School of Earth and Environmental Sciences, \\ The University of Adelaide, Adelaide, SA 5005, Australia
}

5998 words, 202 references, 2 tables, 5 figures

Abbreviated title: Neoproterozoic palaeogeography 


\begin{abstract}
We present two alternative sets of global palaeogeographic reconstructions for the time interval 615 - 530 Ma using competing high and low-latitude palaeomagnetic data subsets for Laurentia in conjunction with geological data. Both models demonstrate a genetic relationship between the collisional events associated with the assembly of Gondwana and the extensional events related to the opening of the Tornquist Sea, the eastern Iapetus Ocean (600 - $550 \mathrm{Ma}$ ), and the western Iapetus Ocean (after $550 \mathrm{Ma}$ ), forming a three-arm rift between Laurentia, Baltica, and Gondwana. The extensional events are probably plume-related, which is indicated in the reconstructions by voluminous mafic magmatism along the margins of palaeocontinents. The low-latitude model requires a single plume event, whereas the high-latitude model needs at least three discrete plumes. Coeval collisions of large continental masses during the assembly of Gondwana, as well as slab pull from subduction zones associated with those collisions, could have caused upper plate extension resulting in the rifted arm that developed into the eastern Iapetus Ocean and Tornquist Sea but retarded development of the western Iapetus Ocean. As a result, the eastern Iapetus Ocean and the Tornquist Sea opened before the western Iapetus Ocean.
\end{abstract}


The Late Neoproterozoic to Early Cambrian is one of the most enigmatic time intervals in the Earth's history. This interval includes: (i) one or more major global-scale glaciations (e.g., Kirschvink, 1992; Hoffman \& Schrag, 2002; Hoffman, 2005), (ii) the explosion of Ediacaran and Cambrian fauna (Knoll, 1992; McCall, 2006), (iii) the final breakup of the Rodinia supercontinent by opening of the Iapetus ocean, Tornquist Sea and Palaeo-Asian ocean (e.g. Bingen et al., 1998; Cawood et al., 2001; Cawood \& Pisarevsky, 2006), and (iv) the assembly of the Gondwana supercontinent by closing the Mozambique, Adamastor and Brasiliano oceans (Pimentel et al., 1999, Collins \& Pisarevsky, 2005). Knowledge of palaeogeography is crucial to understanding these events and possible linkages between them. However, the palaeogeography of this time interval is unresolved (e.g., Hartz \& Torsvik, 2002; Murphy et al., 2004; Collins \& Pisarevsky, 2005; Cawood \& Pisarevsky, 2006; McCausland et al., 2006; Tohver et al., 2006), caused, in part, by controversy over the North American palaeomagnetic data (McCausland \& Hodych, 1998; Pisarevsky et al., 2000, 2001a; Meert \& Van der Voo, 2001, Cawood \& Pisarevsky, 2006) and the relatively poor palaeomagnetic database for other continents (Pisarevsky, 2005). These controversies have led to hypotheses such as Inertial Interchange True Polar Wander (IITWP, Kirschvink et al., 1997; Evans, 1998, Maloof et al., 2006), or an anomalously large non-dipole component of the Earth’s magnetic field (e.g., McCausland et al., 2003).

Development of the Iapetus Ocean is one of the key palaeogeographic events during the late Neoproterozoic to early Palaeozoic time interval. Although there is broad agreement on the timing of the rift-drift stages in its development (e.g., Bingen et al., 1998; Cawood et al., 2001; Williams and Hiscott, 1987), understanding of the 
mechanisms that led its opening remain elusive. In order to gain insights into these mechanisms we utilize regional aspects of the latest Neoproterozoic palaeogeography that have already been published (Powell \& Pisarevsky, 2002; Murphy et al., 2004; Collins \& Pisarevsky, 2005; Cawood \& Pisarevsky, 2006), with some modifications based on recently published data. We focus on the boundary forces affecting the unified LaurentiaBaltica-Amazonia-West Africa plate immediately prior to the onset of the development of Iapetus opening and on the distribution and orientation of dyke swarms in the heart of that plate.

The assembly of Gondwana is broadly coeval with the development of the Iapetus Ocean (Grunow et al., 1996; Cawood, 2005; Buchan \& Cawood, in press). Models for Gondwana assembly have evolved dramatically through the last decade - from a relatively simple situation involving the collision of two large continents, East and West Gondwana (e.g., Dalziel, 1992) to a multi-stage assembly of a number of smaller continents and terranes (Collins \& Pisarevsky, 2005). The latter model includes the accretion of fragments of the future enigmatic Avalonian continent onto the Gondwanan margin - an event that played an important role in Iapetus Ocean history (Murphy et al., 2004).

As the emphasis of this paper is on the potential relationship between the development of the Iapetus Ocean and the assembly of Gondwana, we do not consider other continental blocks, such as North and South China, Indochina, Tarim or Omolon. Only a preliminary model of the Siberian drift history is presented in view of ongoing studies on this continent and the controversy regarding its potential Laurentian connections (Pisarevsky \& Natapov, 2003 and references therein). 


\section{Palaeomagnetic constraints for the latest Neoproterozoic - Early Cambrian drift history}

Table 1 presents the latest palaeopoles for the interval 615 to 530 Ma with a reliability index $\mathrm{Q} \geq 3$ (Van der Voo, 1990), dominated by data from three continents - Laurentia, Baltica, and Australia. Data from Laurentia are relatively abundant, but also controversial in forming two groups of roughly similar reliability, one that supports a low-latitude position for Laurentia and the other that supports a high-latitude position between $\sim 600$ and 560 Ma. Discussion of this controversy is provided by Cawood \& Pisarevsky (2006), but we emphasize that if all these late Neoproterozoic palaeopoles are primary and their ages are correctly assigned, then they are difficult to explain through normal plate tectonic mechanisms and processes such as IITPW or a more rapid style of plate tectonics may need to be invoked (e.g. Evans, 2003). An alternative explanation is that some of these data are misleading, being either the result of remagnetisation or incorrect deciphering of the palaeomagnetic signal (e.g. Hodych et al., 2004). We think that the question is still open and at present it is impossible to indicate any preference between the two datasets. Accordingly, we evaluate the tectonic significance of two alternative models for the latest Neoproterozoic - Early Cambrian palaeogeography, naming them as "high-latitude" and "low-latitude" models depending on the chosen set of Laurentian palaeopoles.

Palaeopoles for Baltica between 650 and $540 \mathrm{Ma}$ (Table 1) are also incompatible with a smooth Apparent Polar Wander Path (APWP), and several alternative APWPs 
Table 1. Late Neoproterozoic and Early Cambrian palaeomagnetic poles.

\begin{tabular}{|c|c|c|c|c|c|}
\hline \multirow[t]{2}{*}{ Object } & \multicolumn{2}{|c|}{ Pole } & \multirow{2}{*}{$\begin{array}{c}\mathrm{dp} / \mathrm{dm} \\
\left({ }^{\circ}\right) \\
\end{array}$} & \multirow{2}{*}{$\begin{array}{l}\text { Age } \\
(\mathrm{Ma}) \\
\end{array}$} & \multirow[t]{2}{*}{ Reference } \\
\hline & $\left({ }^{\circ} \mathrm{N}\right)$ & $\left({ }^{\circ} \mathrm{E}\right)$ & & & \\
\hline \multicolumn{6}{|l|}{ Baltica } \\
\hline Egersund Dykes, Norway & -28 & 232 & $15 / 18$ & $3616 \pm 3$ & Storetvedt (1966); Bingen et al. (1998) \\
\hline Egersund Dykes, Norway & -22 & 231 & $16 / 21$ & $4616 \pm 3$ & Poorter (1972); Bingen et al. (1998) \\
\hline Fen Complex, Norway & -56 & 330 & $7 / 10$ & $4583 \pm 15$ & Meert et al. (1998) \\
\hline Winter Coast sediments, Russia & 25 & 312 & $2 / 4$ & $6555.3 \pm 0.3$ & Popov et al. (2002); Martin et al. (2000) \\
\hline Zolotitsa sediments, Russia & 32 & 293 & $2 / 3$ & $6550 \pm 5$ & Popov et al. (2005) \\
\hline Verkhotina sediments, Russia & 32 & 287 & $2 / 3$ & $5550 \pm 1$ & Popov et al. (2005) \\
\hline Zolotitsa sediments, Russia & 28 & 290 & $4 / 4$ & $6550 \pm 5$ & Iglesia Llanos et al., 2005 \\
\hline Volhynia lavas \& tuffs*, Russia & 34 & 306 & - & $4551 \pm 4$ & Nawrocki et al. (2004); Compston et al. (1995) \\
\hline Torneträsk Formation, Sweden & 56 & 296 & $12 / 15$ & $4545-520$ & Torsvik and Rehnström (2001) \\
\hline \multicolumn{6}{|l|}{ Laurentia } \\
\hline Long Range Dykes (5 dykes)** & 19 & 355 & $15 / 21$ & $5615 \pm 2$ & Murthy et al. (1992); Kamo and Gower (1994) \\
\hline Cloud Mountain Basalt & -5 & 352 & $2 / 4$ & $3605 \pm 10$ & Deutsch \& Rao (1977); Stukas \& Reynolds (1974) \\
\hline Callander Complex & 46 & 301 & $6 / 6$ & $5575 \pm 5$ & Symons \& Chiasson (1991) \\
\hline Catoctin Volcanics A & 43 & 308 & $9 / 9$ & $5564 \pm 9$ & Meert et al. (1994); Aleinikoff et al. (1995) \\
\hline Catoctin Volcanics B & 4 & 13 & $10 / 10$ & $4564 \pm 9$ & Meert et al. (1994); Aleinikoff et al. (1995) \\
\hline Sept Iles Intrusion A & -20 & 321 & $5 / 9$ & $5565 \pm 4$ & Tanczyk et al. (1987); Higgins \& van Breemen (1998) \\
\hline Sept Iles Dykes B & 59 & 296 & $10 / 10$ & $4<565 \pm 4$ & Tanczyk et al. (1987); Higgins \& van Breemen (1998) \\
\hline Buckingham lavas & 10 & 341 & $7 / 10$ & $4573 \pm 32$ & Dankers and Lapointe (1981) \\
\hline Johnnie Formation & 10 & 342 & $5 / 10$ & $4570 \pm 10$ & Van Alstine \& Gillett (1979); Hodych et al. (2004) \\
\hline Skinner Cove Formation & -15 & 337 & $9 / 9$ & $4550 \pm 3$ & McCausland \& Hodych (1998); Cawood et al. (2001) \\
\hline \multicolumn{6}{|l|}{ Australia } \\
\hline Yaltipena Fm., SA & -44 & 353 & $8 / 8$ & $7620-630$ & Sohl et al., 1999 \\
\hline Elatina Fm., SA & -39 & 6 & 9/9 & $7600-620$ & Sohl et al., 1999 \\
\hline Elatina Fm., SA & -52 & 347 & $11 / 11$ & $7600-620$ & Schmidt and Williams, 1995 \\
\hline Elatina Fm., SA & -54 & 327 & $1 / 1$ & $6600-620$ & Schmidt et al., 1991 \\
\hline Elatina Fm., SA & -51 & 337 & $2 / 2$ & $5600-620$ & Embleton \& Williams, 1986 \\
\hline Brachina Fm., SA & -33 & 328 & $16 / 16$ & $6590-610$ & McWilliams \& McElhinny, 1980 \\
\hline
\end{tabular}




\begin{tabular}{|c|c|c|c|c|c|}
\hline Bunyeroo Fm., SA & -18 & 16 & $7 / 12$ & $6550-620$ & Schmidt \& Williams, 1996 \\
\hline Albany Belt Dykes & -38 & 347 & $12 / 12$ & $4520-600$ & Harris and Li, 1995 \\
\hline Upper Arumbera Sandstone & -47 & 333 & $3 / 3$ & $7530-560$ & Kirschvink, 1978 \\
\hline Todd River Dolomite & -43 & 340 & $6 / 6$ & $7530-545$ & Kirschvink, 1978 \\
\hline Hawker Group & -21 & 15 & $9 / 9$ & $5530-545$ & Klootwijk, 1980 \\
\hline Antrim Plateau Volcanics & -9 & 340 & $17 / 17$ & $4520-570$ & McElhinny and Luck, 1970 \\
\hline \multicolumn{6}{|l|}{ India } \\
\hline Bhander and Rewa Series & -47 & 33 & $6 / 6$ & $5530-560$ & McElhinny et al.,1978 \\
\hline \multicolumn{6}{|l|}{ Amazonia } \\
\hline Puga Cap Carbonate & 83 & 113 & $6 / 9$ & $4580-630$ & Trinidade et al., 2003 \\
\hline \multicolumn{6}{|l|}{ Gondwana } \\
\hline Mean 540 -560 Ma pole & -10 & 330 & $7 / 7$ & $540-560$ & McElhinny et al., 2003 \\
\hline Mean Early Cambrian pole & 23 & 334 & $15 / 15$ & $525-540$ & McElhinny et al., 2003 \\
\hline \multicolumn{6}{|l|}{ Siberia } \\
\hline Bolshaya Lena redbeds & 3 & 348 & $6 / 10$ & 5 542-630 & Pisarevsky et al., 2000 \\
\hline Minya Fm & 34 & 217 & 9/15 & $3542-630$ & Kravchinsky et al., 2001 \\
\hline Shaman Fm & 32 & 251 & $7 / 14$ & $4542-630$ & Kravchinsky et al., 2001 \\
\hline Biryusa dykes & 25 & 301 & $14 / 28$ & $4608-618$ & Metelkin et al., 2005 \\
\hline Kesyussa Fm, Olenek River & 38 & 345 & 9/15 & $5535-542$ & Pisarevsky et al., 1997 \\
\hline Lena River sediments & 17 & 245 & $3 / 6$ & $5513-542$ & Kirschvink \& Rozanov, 198 \\
\hline
\end{tabular}

Note: Q - Quality factor after Van der Voo (1990) and ranges from 0 to 7 with the later representing the highest quality data * mean of two poles

** recalculated by Hodych et al. (2004) 
have been debated (Popov et al., 2002). This issue is also discussed by Cawood \& Pisarevsky (2006) but, importantly, a consistent group of 550 - 555 Ma palaeopoles from both northern and southern Baltica (Popov et al., 2002, 2005; Iglesia Llanos et al., 2005; Nawrocki et al., 2004) and the coeval Skinner Cove Laurentian pole (McCausland \& Hodych, 1998) undoubtedly indicate that Baltica was separated from Laurentia by 550 Ma (cf. Cawood et al., 2001).

In Australia, palaeomagnetic information from a drill hole through strata in the Neoproterozoic Officer basin shows that Australia probably inhabited low latitudes from 820 Ma until the Early Cambrian (Pisarevsky et al., 2001b; Pisarevsky, 2001;

Pisarevsky et al., in press). From 650 Ma to 550 Ma there is a swathe of palaeopoles, albeit with poor age constraints in many cases. Nevertheless, they form a consistent pattern that places Australia in low latitudes throughout this time, with the southern margin of the continent being near the equator at 600 Ma (Schmidt et al., 1991; Schmidt and Williams, 1995; Sohl et al., 1999). One pole from the Bunyeroo Formation, associated with the Acraman impact structure (Schmidt and Williams, 1996), falls outside the main group of palaeopoles. This could be evidence for rapid rotation of Australia, or IITPW, at 590 Ma. However, impact-related rocks are not well understood palaeomagnetically. Also, no such deflection in palaeolatitude has been found so far by palaeomagnetic studies of Australian sedimentary sections in drill-holes (Pisarevsky et al., 2001b; Pisarevsky, 2001; Pisarevsky et al., in press).

There are no reliable late Neoproterozoic palaeomagnetic poles from the preassembly Congo or Kalahari blocks. The post-orogenic 547 Ma Sinyai dolerite intrudes the East African orogen and provides a pole for this part of proto-Gondwana (Meert and 
Van der Voo, 1996; McElhinny et al., 2003). In India, palaeomagnetic data from the Bhander and Rewa series are only broadly constrained as Neoproterozoic or Early Cambrian (McElhinny et al., 1978; Evans, 2000). Recently Chirananda De (2003) reported the discovery of medusoid fossils of Ediacaran affinity at the base of Bhander Group, apparently below the strata sampled by McElhinny et al. (1978). If so, the time range for the Bhander pole might be narrowed to between 560 and 530 Ma.

The Puga cap carbonate palaeopole from Amazonia (Trindade et al., 2003) indicates low latitude for Amazonia around $600 \mathrm{Ma}$. This pole is suspiciously close to the present-day pole, so it may represent a recent remagnetisation. However, the possibility that this pole is correct and that São Francisco/Congo did not collide with Amazonia until after 635 Ma along the Pampean-Araguaia Orogen cannot be discounted (Trindade et al. 2006).

The latest Neoproterozoic Siberian palaeomagnetic database is controversial. The poles are derived from sedimentary successions that are poorly dated (Table 1). The only reasonably well dated pole is from the 612 Ma Biryusa dykes (Metelkin et al., 2005; age from Gladkochub et al., 2006), but has been calculated from only three dykes. Possible reasons for the discordance of Siberian poles have been discussed previously (e.g., Pisarevsky et al., 1997; Smethurst et al., 1998), including IITWP (Evans, 1998). The reconstructions used in those discussions placed the northern margin of Siberia against the northern margin of Laurentia. Recently published Late Mesoproterozoic palaeomagnetic data (Gallet et al., 2000; Pavlov et al., 2000, 2002) suggest that the only permissible configuration at 1050 - 950 Ma involved Siberia separated from Laurentia with its southern margin facing towards the northern margin of Laurentia (Pisarevsky \& 
Natapov, 2003). On the other hand, the mid-Cambrian position of Siberia is supported by good palaeomagnetic evidence (Smethurst et al., 1998), implying that this continent rotated almost 180 degrees during the Neoproterozoic. Possible evidence of a rifting event in southern Siberia (Gladkochub et al., 2006) at 740 Ma implies that this rotation occurred in Late Neoproterozoic times.

\section{Key fragments of the latest Neoproterozoic - Early Cambrian palaeogeography}

\section{Iapetian realm}

Among various published configurations of Laurentia, Baltica, and Amazonia (e.g., Dalziel, 1997; Hartz \& Torsvik, 2002; Cawood et al., 2003; Pisarevsky et al., 2003), the reconstruction shown in Fig. 1 (after Pisarevsky et al., 2003) is the only one that fits both published palaeomagnetic data and geological constraints (Cawood \& Pisarevsky, 2006). In particular, it is consistent with the existence of the long-lived Meso- to Neoproterozoic passive continental margin along the eastern and north-eastern edge of Baltica (Fig. 1, NB unless otherwise stated, all geographic references are in present coordinates), which was converted into an active margin between 600 and 550 Ma (e.g., Nikishin et al., 1996; Olovyanishnikov et al., 2000; Willner et al., 2001, 2003; Maslov \& Isherskaya, 2002; Roberts \& Siedlecka, 2002; Puchkov, 2003 and references therein). The reconstruction is also supported by the absence of any evidence for the Cambrian rifting and continental break-up along the Uralian margin of Baltica (Maslov et al., 1997) required by other models (e.g. Hartz \& Torsvik, 2002). 


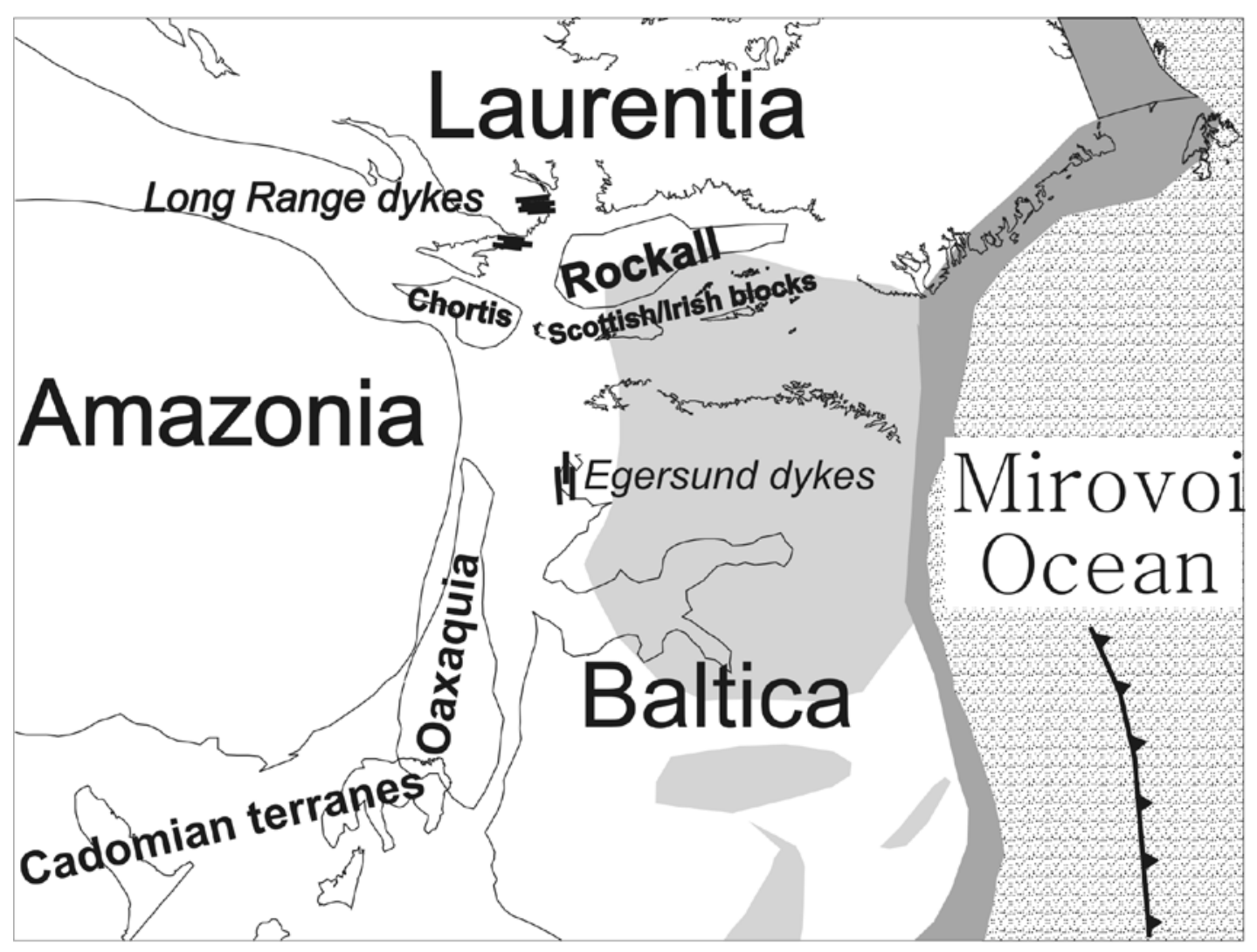

Passive margin $\square$ Intracontinental basins $=615$ Ma mafic dykes

Fig. 1. Pre-Iapetian ( $615 \mathrm{Ma}$ ) palaeogeographic reconstruction of Laurentia, Baltica, and Amazonia.

At the beginning of the Ediacaran ( $630-600 \mathrm{Ma})$, Laurentia, Baltica, and Amazonia, probably still formed a single continental block - the last fragment of the Rodinia supercontinent (Fig. 1), which had begun to disperse between 800 and 750 Ma (Wingate \& Giddings, 2000). The 615 Ma Long Range (Laurentia) and Egersund (Baltica) mafic dyke swarms are both rift-related according to their geochemical characteristics (Bingen et al., 1998; Puffer, 2002) and are possible indicators for the onset of rifting that eventually resulted in the separation of Baltica from Laurentia and 
Amazonia and the opening of both the eastern Iapetus Ocean and the Tornquist Sea (Kamo et al., 1989; Kamo \& Gower, 1994; Bingen et al., 1998; Puffer, 2002). These magmatic events were followed by more widespread rift-related mafic magmatism at 610 - 550 Ma along the eastern margin of Laurentia (Halliday et al., 1989; Cawood et al, 2001; Puffer, 2002), the Scandinavian margin of Baltica (e.g., Bingen et al., 1998; Roberts et al., 2004), and the south-western margin of Baltica (e.g., Compston et al., 1995; Poprawa et al., 1999; Shumlyanskyy \& Andréasson, 2004; Elming et al., 2005). Keppie et al. (2006) reported a ca. 546 Ma plume-related mafic dyke swarm in Oaxaquia, Mexico, which in our reconstruction is in close juxtaposition to the western Ukrainian volcanic province of similar age (e.g., Keppie \& Ramos, 1999; Shumlyanskyy \& Andréasson, 2004; Elming et al., 2005).

The locations of these magmatic provinces and the trends of most of these dyke swarms are shown in Fig. 2. This configuration suggests three branches of a plumerelated rifting event, with the plume centre at the triple point between Laurentia, Baltica and Amazonia. Two of these branches broadly coincide with the strikes of the Grenville and Sveconorwegian orogenic belts, suggesting a degree of inheritance, whereas the third arm, extending between west Baltica and northeast Laurentia, cuts across structural trends (Cawood et al., in press). In western Scandinavia, the rift-to-drift transition occurred around 600 - $580 \mathrm{Ma}$, followed by a developing passive continental margin (Bingen et al., 1998; Greiling et al., 1999; Siedlecka et al., 2004). In contrast, Cawood et al. (2001) reported that the rift-to-drift transition along the Laurentian mainland (juxtaposed to Amazonia in our reconstruction) occurred in Early Cambrian times, i.e. significantly later than in the western Scandinavia, implying failure of the first attempted 
rift between Laurentia and Amazonia, possibly indicated by the 600 Ma Grenville dykes (e.g., Cawood et al., 2001). The second attempt in Early Cambrian time, however, was successful. For two other arms, between Baltica and Rockall/Greenland/Scottish blocks and between Baltica and Oaxaquia/Amazonia, the rift-to-drift transition was successfully completed $\sim 600-580 \mathrm{Ma}$ and led to the opening of the eastern Iapetus Ocean and the Tornquist Sea in Ediacaran times (Bingen et al., 1998; Greiling et al., 1999; Siedlecka et al., 2004).

In our scenario opening of the eastern Iapetus Ocean and Tornquist Sea was followed by the opening of the western Iapetus Ocean when Amazonia and Laurentia broke apart (Fig. 2). The configuration of the rifting zone between these two continents has been proposed by Thomas (2005, and references therein). A similar model has been proposed by Bingen et al. (1998), but their initial configuration places Baltica against East Greenland. The configuration shown in Figs. 1 and 2 is consistent with published palaeomagnetic data (Cawood \& Pisarevsky, 2006, and references therein). Moreover, Greiling \& Smith (2000) noted similarities between the Neoproterozoic sedimentary successions in Scandinavia and Scotland, and proposed a similar Laurentia-Baltica fit. Carbonatite intrusions in Baltica (the 584 Ma Fen and 589 Ma Alnø complexes, Meert et al, 1998; Walderhaug et al., 2003) and in Laurentia/Greenland at 574 Ma (St. Honore, Doig \& Barton, 1968) and 600 Ma (Sarfartoq, Greenland, Larsen \& Rex, 1992) also surround the centre of the suggested plume, supporting our reconstruction. Recent palaeomagnetic data showing that Baltica and Laurentia were well separated at $~ 550 \mathrm{Ma}$ implies that the eastern Iapetus Ocean and the Tornquist Sea were already open by that time. This is in accord with the model shown in Fig.2. 


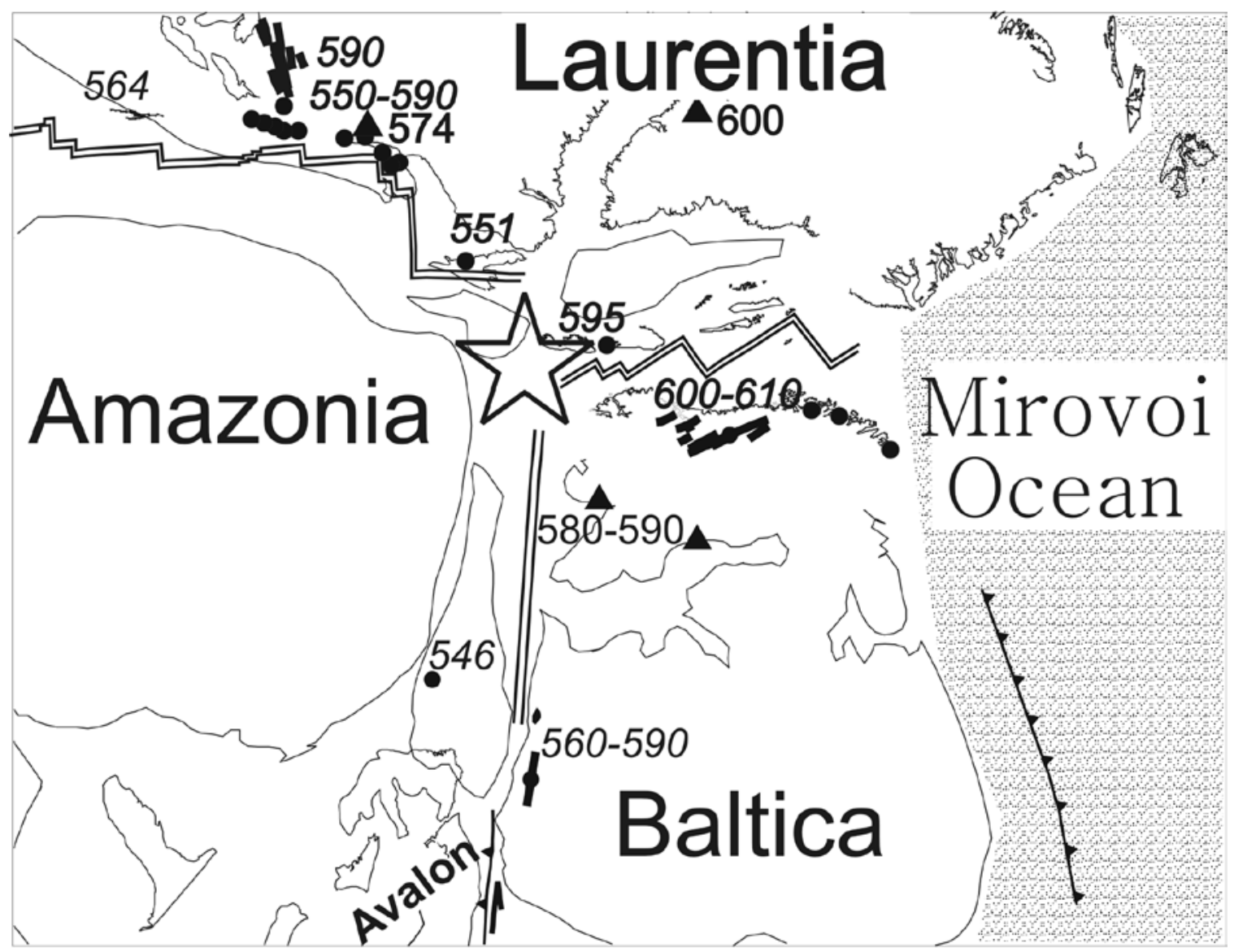

564 Rift-related mafic magmatism, = Mafic dyke swarms ages in $\mathrm{Ma}$

$\Delta 574$ Carbonatites, ages in Ma

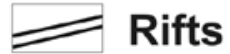

$y$ Subduction zones

* Possible plume centre

Fig. 2. Distribution of mafic magmatic rocks along incipient rifts between Laurentia, Baltica, and Amazonia at 600 - 550 Ma.

Mirovoian realm

Mirovoi is the name given to the ocean that surrounded Rodinia (McMenamin \& McMenamin, 1990), and we extend that definition here to denote the ocean that surrounded Laurentia-Baltica-Amazonia-West Africa immediately prior to Iapetan 
rifting. We now examine regional tectonothermal events that are coeval with the development of the Iapetus Ocean and evaluate potential geodynamic linkages between these two oceans.

The failure of the Laurentia-Amazonia rift was coeval with oblique subduction beneath the Avalonian-Cadomian belt (Fig. 2) along the northern margin of Amazonia/West Africa (Murphy et al., 2004). We suggest that there may be a geodynamic linkage between these events: subduction directed beneath Amazonia/West Africa could create a counter-force against this rifting of the southern margin of Laurentia. Additionally, the sinistral strike-slip component of Avalonian subduction (Murphy et al., 2000) may have provided an additive force for the rifting between Baltica and Amazonia/Oaxaquia (Fig. 2).

Along the north-eastern margin of Baltica, Roberts \& Siedlecka (2002) proposed that in early Ediacaran time there was a subduction zone outboard of the Timanian part of the Baltican margin, directed oceanward (Fig. 2; see also figure 8 of Roberts \& Siedlecka, 2002). On the eastern margin of Amazonia, the development of an arc along the margins of the São Francisco craton (Pimentel et al., 1999) indicates another subduction zone outboard of, and directed away from, Amazonia/West Africa. Taken together, the slab-pull forces associated with these subduction zones would also be consistent with the separation of Baltica from Amazonia/Oaxaquia.

\section{Assembly of Gondwana}

Hypotheses about the assembly of Gondwana in the Proterozoic (see Collins \& Pisarevsky, 2005 for an overview) may be subdivided into three groups: (i) one rigid 
block, a part of a single supercontinent (e.g. Piper, 2000); (ii) two large Neoproterozoic continental masses - East Gondwana (India-Australia-Antarctica) and West Gondwana (Africa-South America) that amalgamated by the end of Neoproterozoic (e.g., McWilliams, 1981; Dalziel, 1992); and (iii) a number of separately drifting continental fragments that assembled by the latest Neoproterozoic - Early Palaeozoic (e.g., Meert et al., 1995; Torsvik et al., 2001; Powell \& Pisarevsky, 2002; Pisarevsky et al., 2003; Collins \& Pisarevsky, 2005; Trindade et al., 2006).

Trompette $(1994,1997)$ proposed the existence of a single West AfricaAmazonia-Rio de La Plata mega-craton in the Meso- and Neoproterozoic on the basis of similarities between the Proterozoic sedimentary successions of three blocks. However, he did not exclude the possibility of minor relative movements between its components. Some palaeomagnetic data indicate the possibility of shearing between Amazonia and West Africa (Onstott \& Hargraves, 1981), but no conclusive evidence has been published.

Rio de La Plata is a poorly known craton, with only a few reliable palaeomagnetic data, that generally support an affinity to Amazonia (Trompette, 1994, 1997). Its Precambrian dimensions are similarly uncertain. The Rio de La Plata block, as depicted by Dalziel (1997), for example, included parts of the Pampean terrane as well as the southern extremity of the Guapore block. In contrast, Ramos (1988) envisaged a Pampean - Rio de La Plata collision at 600 - 570 Ma, although recent studies suggest that this could have happened even later, at 530 - 520 Ma (e.g., Trindade et al., 2006). Trompette (1994) considered the possibility of an Amazonian affinity for the southern Guapore cratonic extension. Pimentel et al. (1999) suggested a collision between the São 
Francisco craton and the Paraná block between 790 and 750 Ma. In our reconstructions (Fig. 3), we propose three separate blocks: 1) Rio de La Plata sensu stricto, which includes basement to the NE and SW of Buenos Aires (Cingolani and Dalla Salda, 2000), but does not include the Luis Alves block and the southern extremity of the Guapore Block, 2) the Pampean terrane, and 3) the Paraná block.

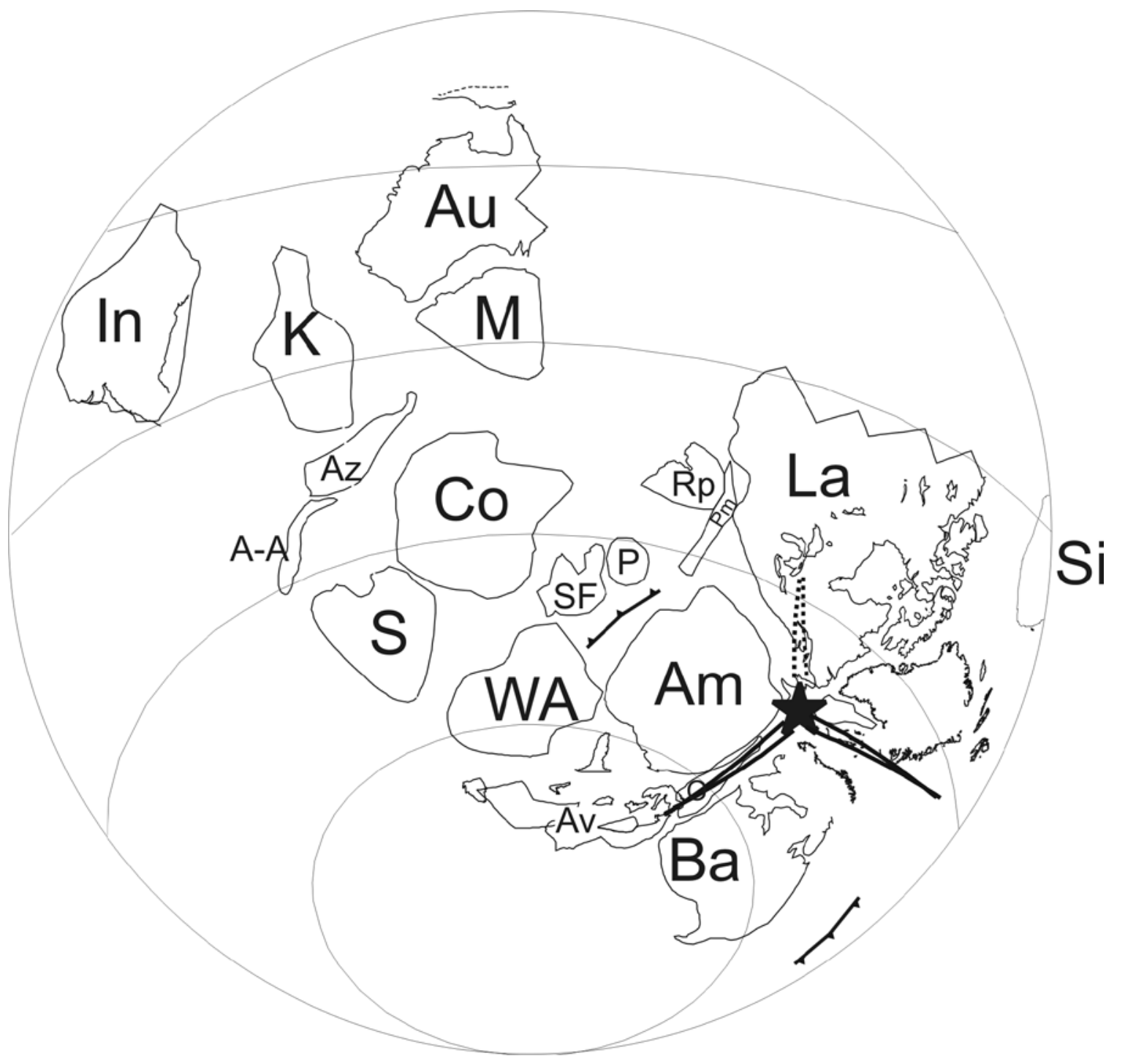

Fig.3. Palaeogeography at $\sim 600 \mathrm{Ma}$. Star denotes the centre of a mantle plume.

Successive rifts between Baltica and Laurentia, and between Baltica and Amazonia are shown with solid lines; failed rift between Laurentia and Amazonia is shown with dotted 
lines. Subduction zones outboard of Baltica and Amazonia are directed in opposite directions creating an extensional strain by slab push forces. A-A - Afif-Abas; Am Amazonia; Au - Australia; Av - Avalonia; Az - Azania; Ba - Baltica; Co - Congo; In India; K - Kalahri; La - Laurentia; M - Mawson; O - Oaxaquia; P - Paraná; Pm Pampean; Rp - Rio de La Plata; S - Saharan Metacraton; SF - São Francisco; Si Siberia.

However, we must emphasize that to the best of our knowledge there are no palaeomagnetic data from Pampean terrane and Paraná block, so their inclusion in our reconstructions (Figs. 4 and 5) are open to dispute. We have generally followed the tectonic model of Ramos (1988) for the Rio de La Plata and Pampean blocks, keeping them in the vicinity of Laurentia, and the model of Pimentel et al. (1999) for Paraná São Francisco collision. Recent palaeomagnetic data (Sánchez-Bettucci \& Rapalini, 2002; Rapalini, 2006) suggest that Rio de La Plata was part of Gondwana by 550 Ma. These data together with other publications (i.e. Rapela et al., 2005) may indicate that our approach to a position and role of Rio de La Plata could be an oversimplification and more sophisticated model for this part of the palaeoglobe should be considered in the future, as it was previously suggested by Omarini et al., 1999). 


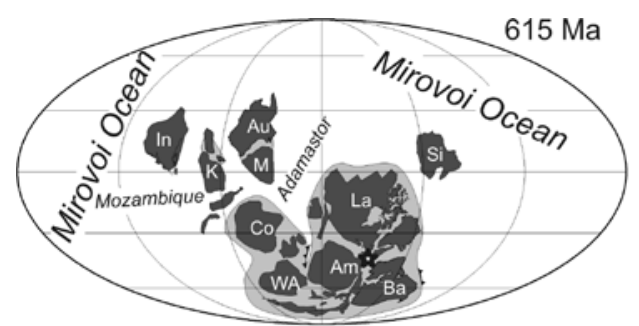

(a)

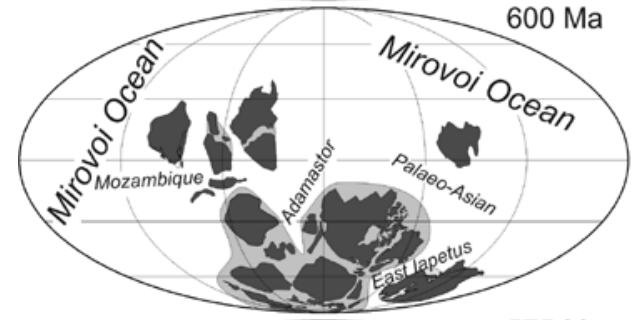

(b)

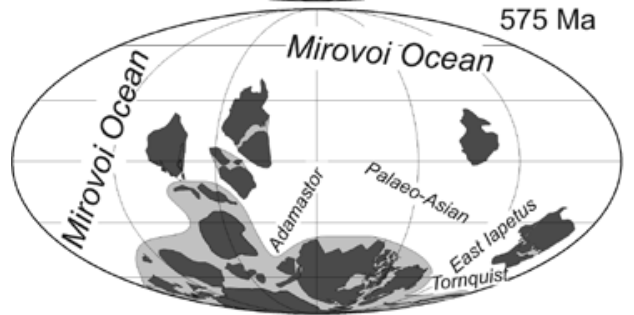

(c)

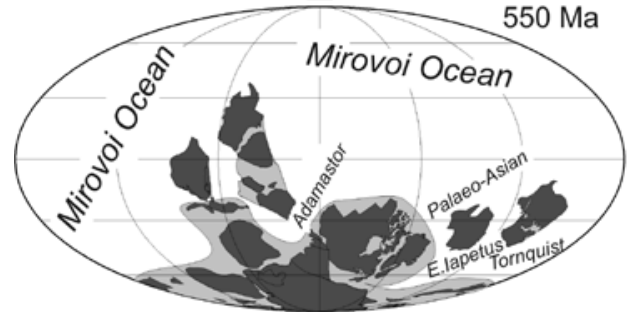

(d)

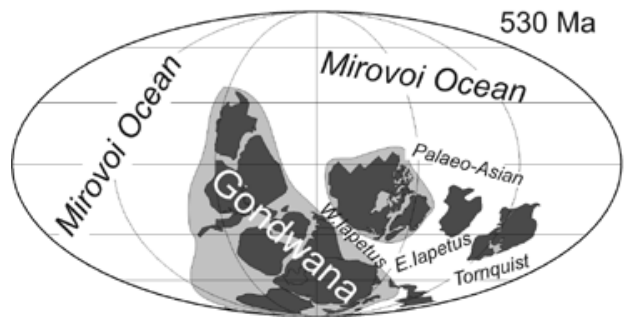

(e)

Fig. 4. Global palaeogeography between

615 Ma and 530 Ma, high-latitude

model. Euler's rotation parameters are in

Table 2.
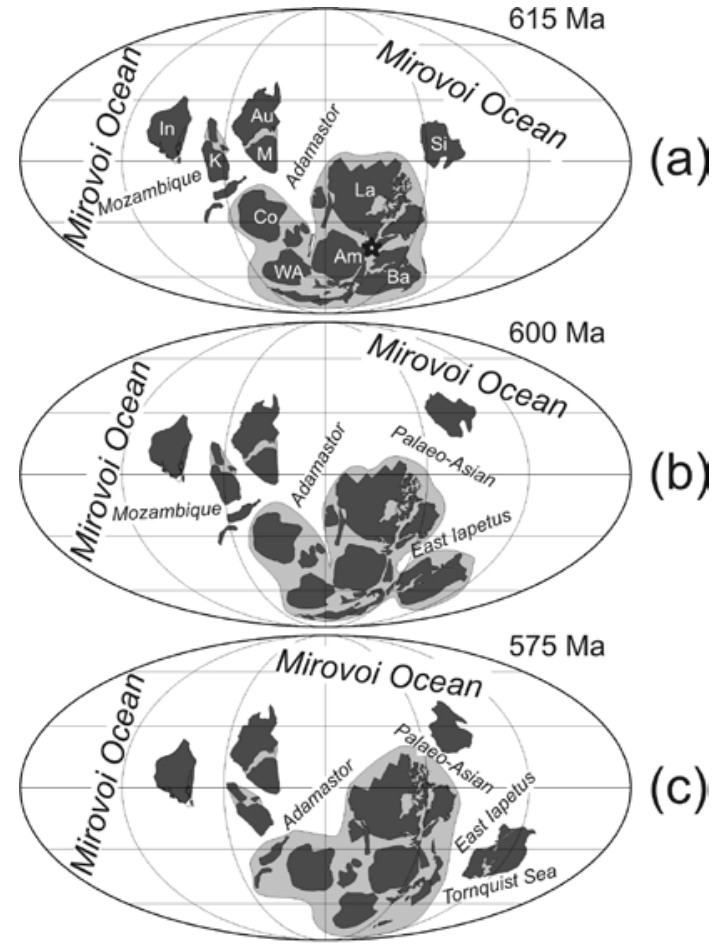

(c)

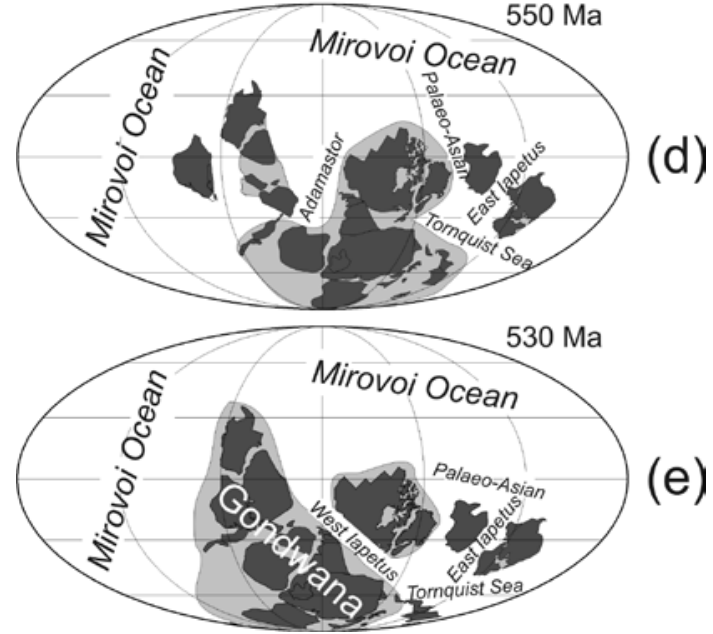

Fig. 5. Global palaeogeography between 615 Ma and 530 Ma, low-latitude model. Euler's rotation parameters are in Table 2. 
The Congo/São Francisco craton, according to palaeomagnetic data (Meert et al., 1995; Wingate et al., 2005) and geological evidence (Kröner \& Cordani, 2003; Collins \& Pisarevsky, 2005), drifted as a separate continent independent of Rodinia. Along its northern margin, peak Neoproterozoic metamorphism accompanied by deformation is reported to have occurred at 630 Ma both in Uganda (Leggo, 1974; Appel et al., 2004) and in the Oubanguides Belt of the Central African Republic (Pin and Poidevin, 1987). This deformation and metamorphism is interpreted to reflect the collision between this block and the poorly known Saharan Metacraton (Abdelsalam et al., 2002), which is composed of a number of pre-Neoproterozoic terranes separated by juvenile Neoproterozoic crust (Black et al., 1994; Caby, 2003; Liégeois et al., 2003). This collision is roughly coeval with the $\sim 650-600$ Ma collision between the São Francisco craton and Amazonia along the Brasília and Araguaia Belts (Pimentel et al., 1991; Moura and Gaudette, 1993; de Alvarenga et al., 2000; Pimentel et al., 2000; Valeriano et al., 2004). In the Dahomeyide Belt, between the collage of pre-Neoproterozoic terranes that make up Nigeria (Dada, 1998) and the West African craton, ${ }^{40} \mathrm{Ar} /{ }^{39} \mathrm{Ar}$ hornblende ages of 590-580 Ma in the suture-zone nappes provide a younger age constraint on the collisions of these terranes with the Congo craton (Attoh et al., 1997). Hence we suggest that the collision between Congo/São Francisco and Amazonia/West Africa occurred before 600 $\mathrm{Ma}$ - roughly coeval with the opening of the eastern Iapetus Ocean and of the Tornquist Sea, and with oblique subduction beneath Amazonia/West Africa that generated ca. 630570 Ma peak magmatism in the Avalonian-Cadomian belt. Smaller continental blocks, such as Afif-Abas and Azania (Collins \& Windley, 2002; Collins \& Pisarevsky, 2005), 
also joined the Congo craton and the Sahara Metacraton roughly at the same time to form the bulk of the East African continent.

Separation between the Kalahari craton and the Congo craton during most of Neoproterozoic is indicated by Meso- to Neoproterozoic eclogites, arc volcanic rocks and ophiolites in the Zambezi Belt (Oliver et al., 1998; Johnson \& Oliver, 2000; John et al., 2003; Johnson \& Oliver, 2004), which characterize the presence of oceanic crust between them. The timing of the collision between Congo and Kalahari along the Irumide/Zambezi/Damara orogenic system is constrained by the age of the high-pressure metamorphism at 560 - 505 Ma (Vinyu et al., 1999; Jung et al., 2000; Hargrove et al., 2003; John et al., 2003; Johnson \& Oliver, 2004; Goscombe et al., 2004). These and other constraints (Collins \& Pisarevsky, 2005) suggest that Kalahari collided with Congo significantly later than the collision between Congo/Saõ Francisco and Amazonia (Prave, 1996).

The assumption of the integrity of East Gondwana (Australia/East Antarctica/India) was challenged by Fitzsimons (2000), who has shown that three sectors of the assumed Grenville-age orogenic belt in East Antarctica are significantly different in age and history and are separated from each other by Pan-African belts. Subsequent studies (see Collins \& Pisarevsky, 2005 for an overview), including palaeomagnetic data (Torsvik et al., 2001), resulted in the proposal that the Australia/Mawson, India/Rayner and Kalahari/Dronning Maud Land blocks amalgamated shortly before (Powell \& Pisarevsky, 2002), or during (Boger et al., 2001) the final amalgamation of Gondwana. In our reconstructions we suggest that this happened at $~ 530$ Ma by the oblique collision of India with Australia/Mawson and East Africa and the coeval docking of 
Kalahari/Dronning Maud Land to Congo along the Ambezi and Damara belts (Collins \&

Pisarevsky, 2005). At this time East Antarctica became a single continental block.

Table 2. Euler rotation parameters (to the absolute framework).

Craton/block/terrane

\begin{abstract}
Cratom/ock/terane
\end{abstract}

High
High-latitude option (Fig.4)
Pole Angle
Pole Angle
$\left({ }^{\circ} \mathrm{N}\right)\left({ }^{\circ} \mathrm{E}\right) \quad\left({ }^{\circ}\right)$
$\left({ }^{\circ} \mathrm{N}\right) \quad\left({ }^{\circ} \mathrm{E}\right)$
$\left({ }^{\circ}\right)$

Low-latitude option (Fig.5)

\begin{tabular}{lllllll}
\hline & \multicolumn{7}{c}{$\mathbf{6 1 5} \mathbf{M a}$} \\
E.Antarctica (Mawson) & 31.3 & 90.6 & 96.4 & 31.3 & 90.6 & 96.4 \\
Dronning Maud Land & 24.2 & 65.5 & 126.1 & 24.6 & 66.0 & 124.2 \\
Australia & 49.0 & 101.3 & 83.4 & 49.0 & 101.3 & 83.4 \\
Congo & 27.6 & 115.5 & 150.7 & 24.8 & 116.8 & 151.5 \\
Kalahari & 50.9 & 81.5 & 141.9 & 51.0 & 83.0 & 140.7 \\
W.Africa & 28.4 & 120.8 & 160.1 & 28.4 & 120.8 & 160.1 \\
India & 67.4 & 133.2 & 80.9 & 67.4 & 133.2 & 80.9 \\
Siberia & 62.1 & -62.4 & -163.9 & 62.1 & -62.4 & -163.9 \\
Rockall & 25.5 & -118.5 & -116.0 & 25.5 & -118.5 & -116.0 \\
E.Avalon & 8.1 & 115.5 & 162.5 & 8.1 & 115.5 & 162.5 \\
Baltica & 23.8 & -92.6 & -140.9 & 23.8 & -92.6 & -140.9 \\
Rio de La Plata & 22.4 & 88.0 & 154.2 & 22.4 & 88.0 & 154.2 \\
São Francisco & 23.3 & 86.6 & 149.0 & 21.0 & 88.4 & 147.0 \\
Pampean & 22.4 & 88.5 & 153.9 & 22.4 & 88.5 & 153.9 \\
Paraná & 23.3 & 86.6 & 149.0 & 21.0 & 88.4 & 147.0 \\
Amazonia & 23.5 & 92.5 & 157.0 & 23.5 & 92.5 & 157.0 \\
Laurentia & 15.4 & -127.4 & -106.8 & 15.4 & -127.4 & -106.8 \\
Chortis & 2.4 & 23.6 & 61.1 & 2.4 & 23.6 & 61.1 \\
Oaxaquia & 15.8 & 96.7 & -151.2 & 15.8 & 96.7 & -151.2 \\
W.Avalon & 10.9 & 85.5 & 159.1 & 10.9 & 85.5 & 159.1 \\
Baffin Land & 16.5 & -124.3 & -109.7 & 16.5 & -124.3 & -109.7 \\
N.Alaska & 34.9 & -95.4 & -159.0 & 34.9 & -95.4 & -159.0 \\
Greenland & 18.9 & -118.7 & -116.9 & 18.9 & -118.7 & -116.9 \\
& & & & & &
\end{tabular}


Table 2 (continue)

\section{$600 \mathrm{Ma}$}

E.Antarctica (Mawson)

Dronning Maud Land

Australia

Congo

Kalahari

W.Africa

India

Siberia

Rockall

E.Avalon

Baltica

Rio de La Plata

São Francisco

Pampean

Paraná

Amazonia

Laurentia

Chortis

Oaxaquia

W.Avalon

Baffin Land

N.Alaska

Greenland

E.Antarctica (Mawson)

Dronning Maud Land

Australia

Congo

Kalahari

$\begin{array}{lll}30.1 & 92.4 & 96.3 \\ 21.3 & 69.1 & 126.3 \\ 47.7 & 103.9 & 83.9 \\ 35.4 & 117.6 & 148.0 \\ 47.4 & 84.2 & 144.6 \\ 35.1 & 121.6 & 151.1 \\ 65.4 & 136.7 & 83.5 \\ 53.4 & -93.0 & -127.7 \\ 17.9 & -122.5 & -122.3 \\ 14.2 & 115.2 & 154.7 \\ 11.4 & -103.2 & -136.3 \\ 31.3 & 85.7 & 157.0 \\ 31.3 & 86.4 & 152.6 \\ 31.3 & 86.1 & 156.6 \\ 31.3 & 86.4 & 152.6 \\ 31.3 & 90.5 & 154.3 \\ 8.6 & -131.9 & -115.4 \\ 4.4 & 17.1 & 75.0 \\ 21.6 & 98.7 & -155.3 \\ 18.0 & 84.2 & 158.2 \\ 9.5 & -128.7 & -117.5 \\ 27.1 & -97.8 & -159.5 \\ 11.6 & -122.9 & -123.4\end{array}$

575 Ma

$\begin{array}{lll}28.1 & 95.4 & 96.3 \\ 16.0 & 86.3 & 112.9 \\ 45.3 & 107.8 & 84.9 \\ 48.6 & 123.0 & 136.9 \\ 37.2 & 102.6 & 145.4\end{array}$

$\begin{array}{lll}30.1 & 92.4 & 96.3 \\ 22.9 & 72.7 & 120.0 \\ 47.7 & 103.9 & 83.9 \\ 25.2 & 122.0 & 150.9 \\ 47.4 & 90.9 & 142.0 \\ 24.8 & 125.2 & 155.1 \\ 65.4 & 136.7 & 83.5 \\ 68.2 & -89.5 & -129.1 \\ 24.8 & -120.4 & -104.7 \\ 3.9 & 119.0 & 155.7 \\ 19.2 & -103.3 & -127.6 \\ 22.7 & 92.1 & 149.9 \\ 22.7 & 93.2 & 145.8 \\ 22.7 & 92.5 & 149.7 \\ 22.7 & 93.2 & 145.8 \\ 22.3 & 96.8 & 148.6 \\ 13.1 & -128.9 & -95.9 \\ 10.4 & 17.3 & 54.7 \\ 11.1 & 99.0 & -160.3 \\ 9.4 & 89.2 & 149.0 \\ 14.6 & -125.6 & -98.5 \\ 36.3 & -97.4 & -148.1 \\ 17.8 & -119.9 & -105.5\end{array}$

$\begin{array}{lll}17.8 & -119.9 & -105.5\end{array}$ 
Table 2 (continue)

\begin{tabular}{|c|c|c|c|c|c|c|}
\hline W.Africa & 46.7 & 123.3 & 137.0 & 18.2 & 132.1 & 147.1 \\
\hline India & 62.6 & 144.9 & 88.3 & 62.6 & 144.9 & 88.3 \\
\hline Siberia & 15.5 & -119.2 & -98.4 & 37.6 & -126.0 & -93.4 \\
\hline Rockall & 6.3 & -128.1 & -134.9 & 23.5 & -124.3 & -86.0 \\
\hline E.Avalon & 18.1 & 106.0 & 135.0 & 9.6 & -60.5 & -131.4 \\
\hline Baltica & 9.0 & 59.2 & 139.8 & 4.6 & -118.6 & -109.6 \\
\hline Rio de La Plata & 44.3 & 82.4 & 154.2 & 20.8 & 100.8 & 135.6 \\
\hline São Francisco & 45.8 & 85.2 & 152.3 & 21.6 & 103.7 & 136.2 \\
\hline Pampean & 44.3 & 82.6 & 153.9 & 20.7 & 101.0 & 135.5 \\
\hline Paraná & 45.8 & 85.2 & 152.3 & 21.6 & 103.7 & 136.2 \\
\hline Amazonia & 44.3 & 86.3 & 150.9 & 19.9 & 104.3 & 135.0 \\
\hline Laurentia & 1.4 & 41.8 & 131.7 & 8.3 & -132.0 & -78.0 \\
\hline Chortis & 6.5 & 9.8 & 99.3 & 26.8 & 2.9 & 48.3 \\
\hline Oaxaquia & 33.4 & 100.7 & -163.7 & 6.0 & 101.4 & -177.5 \\
\hline W.Avalon & 25.3 & 73.7 & 145.4 & 4.3 & 90.3 & 115.0 \\
\hline Baffin Land & 1.0 & 45.0 & 132.6 & 10.7 & -128.3 & -80.2 \\
\hline N.Alaska & 14.1 & -101.2 & -161.4 & 38.8 & -101.4 & -130.1 \\
\hline Greenland & 0.3 & -128.9 & -136.2 & 15.6 & -122.1 & -86.5 \\
\hline \multicolumn{7}{|c|}{$550 \mathrm{Ma}$} \\
\hline E.Antarctica (Mawson) & 23.8 & 100.9 & 91.8 & 23.8 & 100.9 & 91.8 \\
\hline Dronning Maud Land & 18.7 & 100.9 & 102.2 & 18.7 & 100.9 & 102.2 \\
\hline Australia & 40.5 & 116.2 & 82.7 & 40.5 & 116.2 & 82.7 \\
\hline Congo & 42.0 & 126.2 & 137.9 & 25.1 & 133.3 & 142.4 \\
\hline Kalahari & 33.4 & 118.2 & 144.6 & 33.4 & 118.2 & 144.6 \\
\hline W.Africa & 39.3 & 122.2 & 136.0 & 22.5 & 130.4 & 138.8 \\
\hline India & 58.3 & 162.0 & 100.0 & 58.3 & 162.0 & 100.0 \\
\hline Siberia & 3.7 & 47.7 & 151.5 & 1.0 & -128.3 & -118.7 \\
\hline Rockall & 13.5 & -124.7 & -121.0 & 23.6 & -122.8 & -90.4 \\
\hline E.Avalon & 14.9 & 104.3 & 129.8 & 0.8 & -65.6 & -122.1 \\
\hline Baltica & 10.9 & 52.7 & 127.4 & 8.9 & 48.0 & 122.1 \\
\hline Rio de La Plata & 38.1 & 87.7 & 144.2 & 25.2 & 100.6 & 131.4 \\
\hline
\end{tabular}


Table 2 (continue)

\begin{tabular}{|c|c|c|c|c|c|c|}
\hline São Francisco & 41.0 & 90.6 & 147.6 & 27.4 & 103.2 & 136.6 \\
\hline Pampean & 38.1 & 87.7 & 144.2 & 25.2 & 100.6 & 131.4 \\
\hline Paraná & 41.0 & 90.6 & 147.6 & 27.4 & 103.2 & 136.6 \\
\hline Amazonia & 38.1 & 87.7 & 144.2 & 25.2 & 100.6 & 131.4 \\
\hline Laurentia & 4.0 & -134.2 & -115.6 & 9.3 & -130.7 & -82.3 \\
\hline Chortis & 0.5 & 2.7 & 77.8 & 14.9 & -11.7 & 51.1 \\
\hline Oaxaquia & 26.8 & 96.1 & -168.3 & 11.3 & 98.9 & 178.5 \\
\hline W.Avalon & 23.9 & 72.0 & 138.0 & 14.5 & 83.6 & 115.9 \\
\hline Baffin Land & 4.9 & -130.9 & -117.2 & 11.5 & -127.1 & -84.6 \\
\hline N.Alaska & 23.6 & -99.3 & -155.0 & 38.1 & -99.9 & -134.1 \\
\hline Greenland & 7.1 & -124.9 & -122.2 & 15.9 & -121.1 & -91.0 \\
\hline \multicolumn{7}{|c|}{$530 \mathrm{Ma}$} \\
\hline E.Antarctica & 19.4 & 107.9 & 91.5 & 19.4 & 107.9 & 91.5 \\
\hline Dronning Maud Land & 21.8 & 107.5 & 94.1 & 21.8 & 107.5 & 94.1 \\
\hline Australia & 35.2 & 124.1 & 85.5 & 35.2 & 124.1 & 85.5 \\
\hline Congo & 32.3 & 125.9 & 140.1 & 32.3 & 125.9 & 140.1 \\
\hline Kalahari & 32.3 & 125.9 & 140.1 & 32.3 & 125.9 & 140.1 \\
\hline W.Africa & 29.5 & 122.7 & 137.6 & 29.5 & 122.7 & 137.6 \\
\hline India & 51.0 & 165.2 & 126.2 & 51.0 & 165.2 & 126.2 \\
\hline Siberia & 5.8 & -127.5 & -135.6 & 5.8 & -127.5 & -135.6 \\
\hline Rockall & 24.4 & -119.1 & -106.2 & 24.4 & -119.1 & -106.2 \\
\hline E.Avalon & 5.0 & 106.6 & 128.5 & 5.0 & 106.6 & 128.5 \\
\hline Baltica & 0.8 & 67.8 & 105.1 & 2.1 & 58.6 & 118.1 \\
\hline Rio de La Plata & 29.5 & 91.1 & 137.4 & 29.5 & 91.1 & 137.4 \\
\hline São Francisco & 32.2 & 93.7 & 141.5 & 32.2 & 93.7 & 141.5 \\
\hline Pampean & 29.5 & 91.1 & 137.4 & 29.5 & 91.1 & 137.4 \\
\hline Paraná & 32.2 & 93.7 & 141.5 & 32.2 & 93.7 & 141.5 \\
\hline Amazonia & 29.5 & 91.1 & 137.4 & 29.5 & 91.1 & 137.4 \\
\hline Laurentia & 12.9 & -127.8 & -97.6 & 12.9 & -127.8 & -97.6 \\
\hline Chortis & 5.5 & 0.9 & 64.3 & 5.5 & 0.9 & 64.3 \\
\hline Oaxaquia & 19.2 & 96.6 & -171.5 & 19.2 & 96.6 & -171.5 \\
\hline W.Avalon & 16.4 & 75.2 & 127.3 & 16.4 & 75.2 & 127.3 \\
\hline \multicolumn{7}{|l|}{ Table 2 (continue) } \\
\hline Baffin Land & 14.3 & -124.5 & -100.3 & 14.3 & -124.5 & -100.3 \\
\hline N.Alaska & 35.9 & -96.2 & -149.2 & 35.9 & -96.2 & -149.2 \\
\hline Greenland & 17.5 & -118.8 & -107.2 & 17.5 & -118.8 & -107.2 \\
\hline
\end{tabular}




\section{Avalonian and related terranes}

Avalonia and Cadomian are two of a group of terranes, collectively referred to as peri-

Gondwanan. On the basis of faunal, lithostratigraphic, geochemical, and palaeomagnetic data they are traditionally interpreted as remnants of the northern (Amazonian and West African) Gondwanan margin in the Neoproterozoic and Early Palaeozoic (Theokritoff, 1979; Van der Voo, 1988; Murphy and Nance, 1989; Cocks and Fortey, 1990; Keppie, 1993; McNamara et al., 2001; Murphy et al., 2002, 2004; Fortey and Cocks, 2003; Collins and Buchan, 2004), although temporary seaways may have separated Avalonia from Amazonia/West Africa (Landing, 1996, 2005). Peri-Gondwanan terranes are characterized by Neoproterozoic magmatism that records a history of subduction beneath the Amazonian/West African margin (e.g., O’Brien et al., 1983; Keppie, 1993; Murphy et al., 1990; Nance et al., 1991; Egal et al., 1996; Linnemann et al., 2000; von Raumer et al., 2002). Some peri-Gondwanan terranes, such as Avalonia, and Carolinia (Hibbard, 2000; Hibbard et al., 2002), were rifted from Amazonia/West Africa by the Early Ordovician and were subsequently involved in Palaeozoic and Mesozoic orogenesis. As a result, they are preserved as a collection of suspect terranes in the younger orogenic belts of Europe and North America. Avalonia stretches from New England to southeastern Newfoundland (O’Brien et al., 1983; Murphy and Nance, 1989, 1991; Keppie et al., 1991) and includes southeastern Ireland (Max and Roddick, 1989) and southern Britain (Tucker and Pharoah, 1991; Gibbons and Horak, 1996). Other peri-Gondwanan terranes occur in the Armorican massif (Cadomia) of northwestern France (Egal et al., 1996; Strachan et al., 1996), the Iberian peninsula (Quesada, 1990; Eguíluz, et al., 2000; Fernandez-Suarez et al., 2000), isolated inliers in Germany and the Czech Republic (e.g., 
Bohemian Massif, Linnemann et al., 2000; Zulauf et al., 1999), and recently recognized vestiges in the Alpine belt (Neubauer, 2002; von Raumer et al., 2002).

Sm-Nd isotopic data indicate that early arc-related complexes of Avalonia probably formed outboard of the Amazonian/West African margin within the Mirovoi Ocean, whereas their subsequent metamorphism is interpreted as recording their accretion to this margin (Murphy et al., 2000, 2004; 2006; Nance et al., 2002). In contrast, coeval Cadomian arc magmatism is attributed to melting of the West African craton.

At about 635 Ma, Avalonian-Cadomian voluminous Andean-style arc-related activity commenced broadly synchronously along the Amazonian/African margin. Arcrelated rocks typically include calc-alkaline mafic to felsic volcanics, coeval plutons and pull-apart sedimentary basin deposits which contain detritus derived from the arc. Subduction was oblique and had a sinistral component (Nance and Murphy, 1990; Murphy and Nance, 1989; Murphy et al., 1999; Keppie et al., 2003). However, the termination of arc magmatism was diachronous from 590 to 540 Ma (Murphy et al., 1999, 2000; Nance et al, 2002; Keppie et al., 2003), and is marked by the progressive development of an intracontinental strike-slip regime that is interpreted as recording ridge-trench collision, analogous to the Oligocene collision between western North America and the East Pacific Rise and the diachronous initiation of the San Andreas transform margin (Murphy and Nance, 1989; Murphy et al., 1999; Nance et al., 2002).

\section{Middle America Terranes}


In addition to these terranes, several crustal blocks in Middle America contain assemblages with Early Palaeozoic fauna that suggest an origin along the northern Gondwanan margin (Keppie and Ramos, 1999). In the Neoproterozoic-early Palaeozoic, these terranes are thought to have lain along either the northern or the western margin of Amazonia (Keppie \& Ramos 1999; Keppie \& Ortega-Gutiérrez 1999; Keppie et al. 2003). In our reconstructions we choose the first interpretation, which places Oaxaquia between Amazonia and Baltica, because it is supported by the palaeomagnetic data (Ballard et al. 1989) (Figs. 1 and 2). The Yucatan block is thought to have been contiguous with the Florida basement (Suwannee terrane, probably part of Avalonia, Heatherington et al, 1996). The Grenville-age basement of Oaxaquia and the Chortis block is isotopically transitional between that of the Grenville Belt in Laurentia and basement massifs of Grenville age in Colombia (Ruiz et al., 1999) and is attributed to mixing of juvenile Grenville and Archaean sources (Cameron et al. 2004).

The basement rocks of Oaxaquia are best known. They consist of: (1) a metavolcanic-metasedimentary juvenile arc sequence of uncertain age; (2) a c. 1140 Ma, bimodal, within-plate intrusive suite that was deformed and metamorphosed at c. 1100 Ma; (3) a c. 1012 Ma anorthosite-gabbro that was deformed and metamorphosed in the granulite facies at c. 980-1104 Ma; and (4) c. 920 Ma post-tectonic calc-alkaline plutonic rocks (Keppie et al. 2001; Solari et al. 2003; Ortega-Obregón et al. 2003). This sequence of magmatic and metamorphic events is broadly consistent with those of the Sveconorwegian orogeny in Baltica (e.g. Gorbatschev \& Bogdanova 1993).

\section{5 - 530 Ma palaeogeography}


We choose $615 \mathrm{Ma}$ as a starting point for our reconstructions for the following reasons:

(i) the Long Range dykes in Laurentia and Egersund dykes in Baltica are precisely dated at $615 \mathrm{Ma}$ and are indicators of the beginning of rifting events in these areas; (ii) there are several reasonably reliable $(\mathrm{Q} \geq 3$, Table 1$)$ published palaeopoles of this age (Murthy et al., 1992; Kamo \& Gowler, 1994; Storetvedt, 1966; Poorter, 1972; Bingen et al., 1998; Embleton \& Williams, 1986; Schmidt et al., 1991; Schmidt \& Williams, 1995; Sohl et al., 1999; Metelkin et al., 2005), so that the relative locations of Laurentia, Baltica, Australia, India, and Siberia are reasonably well constrained; (iii) our reconstructions for $615 \mathrm{Ma}$ are identical for both high- and low-latitude models for Laurentia (Fig. 4a and 5a). These diagrams are slightly simplified versions of the reconstruction shown in Fig. 3. We did not use the Amazonian Puga cap carbonate pole (Trindade et al., 2003) and the Australian Bunyeroo pole (Schmidt \& Williams, 1996) for the reasons outlined earlier. The ages of the Siberian poles are poorly constrained and so we urge caution in interpreting the movement of Siberia in Figures 4 and 5. Thus the size and shape of the Palaeo-Asian Ocean are schematic.

\section{High-latitude model (Fig. 4)}

Laurentian palaeopoles from Table 1 used for this model are: (i) Long Range dykes (data recalculated by Hodych et al., 2004), (ii) Callander Complex, (iii) Catoctin Volcanics A, (iv) Sept Iles Dykes B, and (v) Skinner Cove Formation.

Laurentia/Amazonia/West Africa moved gradually to the south, Baltica generally followed them initially, but started to separate at $~ 600$ Ma through the opening of the eastern Iapetus Ocean and the Tornquist Sea (Fig. 4a, b). Australia/Mawson remained at 
equatorial latitudes. A number of collisions occurred that culminated in the formation of Gondwana. Congo/São Francisco collided with Amazonia, closing the Brasiliano Ocean by 570 Ma. The final collision of the Sahara Metacraton with the Tuareg block and West Africa to form the northern part of Gondwana was completed by 600 Ma (Attoh et al., 1997). Kalahari drifted southeastwards closing the Adamastor Ocean and collided with Congo and Rio de La Plata by 530 Ma. India collided obliquely with Australia/Mawson and East Africa at about the same time. These collisional events could have created southward-directed stresses on the rest of Gondwana, inhibiting it from moving northwards with Laurentia after 550 Ma. This possibly caused Laurentia’s separation from Gondwana by opening of the western Iapetus Ocean. Subduction beneath Amazonia/West Africa started at around $600 \mathrm{Ma}$, creating supportive stresses for the opening of the Tornquist Sea and opposing rifting between Laurentia and Amazonia. Puffer (2002) suggested that one or two mantle plumes caused the 615-550 Ma mafic magmatism along the east Laurentian margin. The high-latitude model is inconsistent with either of the proposed plumes, if we assume that they were initiated below the asthenosphere. The suggested plume head(s) should occur near $30^{\circ} \mathrm{S}$ at 615 Ma, near the south pole at $575 \mathrm{Ma}$ and at $60^{\circ} \mathrm{S}$ at $550 \mathrm{Ma}$, so at least three discrete plume events are necessary. The migration of Laurentia to high latitudes implied by this model would predict a 615-575 Ma plume track across Laurentia that also would have influenced the Ediacaran-aged passive margin successions deposited along the western margin (modern coordinates). There is no evidence of this plume track and subsidence curves calculated for these successions (Bond et al., 1984) do not show evidence for a thermal perturbation. 


\section{Low-latitude model (Fig. 5)}

Laurentian palaeopoles we used for this model are: (i) Long Range dykes (as above), (ii) Cloud Mountain Basalt, (iii) Catoctin Volcanics B, (iv) Sept Iles Intrusion A , (v) Buckingham Lavas, (vi) Johnnie Formation, and (vii) Skinner Cove Formation. In this model, Laurentia remained at equatorial latitudes between 615 and $530 \mathrm{Ma}$ and Laurentia/Amazonia/West Africa rotated about 40 degrees anticlockwise. This rotation was possibly connected to the collision of Congo/São Francisco with Amazonia/West Africa and the closure of the Brasiliano Ocean. Baltica rifted away from Laurentia and Amazonia after $\sim 600 \mathrm{Ma}$, but not as rapidly as in the high-latitude model. Gondwana assembly occurred in a similar way to the high-latitude model, but with less motion of West Gondwana and, correspondingly, slower relative movement of Kalahari and India with respect to West Gondwana. Nevertheless, docking of Kalahari and India probably still created enough force for the southward motion of Gondwana, which in this scenario facilitated the opening of the western Iapetus Ocean by separation of Gondwana from Laurentia.

As Laurentia drifted only a small distance between 615 and 530 Ma in the lowlatitude model, it is consistent with the plume hypothesis of Puffer (2002), requiring only a single stationary plume.

The relationship between Gondwanan and Iapetian events Regardless of the chosen scenario of the palaeogeographical development between 615 and $530 \mathrm{Ma}$, it is probable that major events are genetically related. The opposing 
directions of the subduction outboard of the north-eastern margin of Baltica (Roberts \& Siedlecka, 2002) and outboard of the south-western margin of Amazonia (indicated by the presence of a Neoproterozoic magmatic arc on the northwestern margin of the SaoFrancisco-Congo craton, Pimentel et al., 1999) would have necessitated the existence of an extensional regime between these two continents (Figs 4a and 5a). This extensional strain may have supported the rifting along the Tessyer-Tornquist margin of Baltica caused by the coeval mantle plume (Figs 4a and 4a).

The oblique docking of Avalonia to the northern margin of Gondwana at $650 \mathrm{Ma}$ followed by the oblique subduction which produced 630-570 Ma arc magmatism (Murphy et al., 2004), together with the final docking of Congo/São Francisco to Amazonia (Collins \& Pisarevsky, 2005) resulted in a combined force on Amazonia inhibiting its separation from Laurentia (Figs 4b,c and 5b,c). As a result, Baltica drifted away from Laurentia/Amazonia and the eastern Iapetus and the Tornquist Sea opened, but the rifting arm between Laurentia and Amazonia failed (Figs 4b,c and 5b,c). Another plume event near the eastern Laurentian margin (in the high-latitude margin), or the same one (in the low-latitude model), as was suggested by Puffer (2002), is supported by the southward-directed stresses on Gondwana caused by the final docking of Kalahari and India from the north and resulted in the separation between Laurentia and Gondwana and in the opening of the western Iapetus Ocean (Figs 4d,e and 5d, e).

Both sets of palaeogeographic reconstructions (Figs 4 and 5) also show the drift of Siberia, permissible within the age uncertainties of published palaeomagnetic data (Table 1). However, this part of our models should be considered as preliminary due to a number of the ongoing studies in Siberia which may cause significant changes. 


\section{Conclusions}

Two alternative models for the latest Neoproterozoic - Early Palaeozoic global palaeogeography are based on two subsets of the Laurentian palaeomagnetic poles. These groups of palaeopoles are of similar reliability, and new studies are required to distinguish between these models. Alternatively, a non-uniformitarian approach, such as IITPW or non-dipole field could be invoked to explain the results. Both models suggest a geodynamic relationship between the amalgamation of Gondwana and the opening of the Iapetus Ocean. Although both models suggest plume-related rifting between Laurentia, Baltica and Gondwana, the low-latitude model requires a single plume, whereas the highlatitude model needs more than one plume. These rifting events are indicated by voluminous mafic magmatism on the opposite margins of these palaeocontinents and by the rift-drift transition in the sedimentary successions along these margins. Another difference between the two models is the manner of the opening of the western Iapetus Ocean - through the northward movement of Laurentia in the high-latitude model and through the southward movement of Gondwana in the low-latitude model. The openings of the eastern and western Iapetus Ocean and the Tornquist Sea are genetically related to the subduction processes around Amazonia/Baltica and the collisional dockings of Congo, Kalahari, and India that resulted in the assembly of Gondwana.

\section{Acknowledgments}

Pisarevsky and Collins are grateful to St. Francis Xavier University for the W. F. James Professorship. We thank V. Ramos and A. Rapalini for their reviews. 
Reconstructions were made using PLATES software from the University of Texas at Austin and the GMT software of Wessel and Smith. This paper forms the Tectonics Special Research Centre publication No. \#\#\#. 


\section{References}

Abdelsalam, M.G., Liégeois, J.P. \& Stern, R.J. 2002. The Saharan Metacraton. Journal of African Earth Sciences, 34, 119-136.

Aleinikoff, J.N., Zartman, R.E., Walter, M., Rankin, D.W., Lyttle, P.T. \& Burton, W.C. 1995. U-Pb ages of metarhyolites of the Catoctin and Mount Rogers formations, central and southern Appalachians: Evidence for two phases of Iapetan rifting. American Journal of Science, 295, 428-454.

Appel, P.W.U., Schenk, V. \& Schumann, A. 2004. P-T conditions and metamorphic ages of pelitic schists at Murchison Falls (NW Uganda): evidence for a Pan-African event within the cratonic crust of Uganda. 20th Colloquium of African Geology, BRGM, Orléans, France, pp. 49.

Attoh, K., Dallmeyer, R.D. \& Affaton, P. 1997. Chronology of nappe assembly in the Pan-African Dahomeyide orogen, West Africa: Evidence from Ar-40/Ar-39 mineral ages. Precambrian Research, 82, 153-171.

Ballard, M.M., Van der Voo, R. \& Urrutia-Fucugauchi, J. 1989. Paleomagnetic results from Grenvillian-aged rocks from Oaxaca, Mexico: evidence for a displaced terrane. Precambrian Research, 42, 343-352.

Bingen, B., Demaiffe, D. \& van Breemen, O. 1998. The 616 Ma old Egersund basaltic dike swarm, SW Norway, and Late Neoproterozoic opening of the Iapetus Ocean. The Journal of Geology, 106, 565-574. 
Black, R., Latouche, L., Liégeois, J.P., Caby, R. \& Bertrand, J.M. 1994. Pan-African displaced terranes in the Tuareg shiled (central Sahara). Geology, 22, 641-644.

Boger, S.D., Wilson, C.J.L. \& Fanning, C.M. 2001. Early Paleozoic tectonism with the East Antarctic craton: the final suture between east and west Gondwana. Geology, 29, 463-466.

Bond, G.C., Nickerson, P.A. \& Kominz, M.A. 1984. Breakup of a supercontinent between 625 Ma and 555 Ma: New evidence and implications for continental histories. Earth and Planetary Science Letters, 70, 325-345.

Buchan C. \& Cawood, P.A. 2007. Linking accretionary orogenesis with supercontinent assembly. Earth-Science Reviews, in press.

Caby, R. 2003. Terrane assembly and geodynamic evolution of central-western Hoggar: a synthesis. Journal of African Earth Sciences, 37, 133-159.

Cameron, K.L., Lopez, R., Ortega-Gutiérrez, F., Solari, L.A., Keppie, J.D. \& Schulze, C. 2004. U-Pb constraints and Pb isotopic compositions of leached feldspars: Constraints on the origin and evolution of Grenvillian rocks from eastern and southern Mexico, In: Tollo, R.P., Corriveau, L., McLelland, J. \& Bartholomew, M.J. (eds) Proterozoic Tectonic Evolution of the Grenville Orogen in North America. Geological Society of America Memoir, 197, 755-770.

Cawood, P.A. 2005. Terra Australis Orogen: Rodinia breakup and development of the Pacific and Iapetus margins of Gondwana during the Neoproterozoic and Paleozoic. Earth-Science Reviews, 69, 249-279. 
Cawood, P.A. \& Pisarevsky, S.A. 2006. Was Baltica right way up or upside down in the Neoproterozoic? Journal of the Geological Society, London, 163, 753-759.

Cawood, P.A., Nemchin, A.A., Smith, M. \& Loewy, S. 2003. Source of the Dalradian Supergroup constrained by $\mathrm{U} / \mathrm{Pb}$ dating of detrital zircon and implications for the East Laurentian margin. Journal of the Geological Society, London, 160, 231-246.

Cawood, P.A., Nemchin, A.A., Strachan, R.A., Prave, A.R. \& Krabbendam, M. 2007. Sedimentary basin and detrital zircon record along East Laurentia and Baltica during assembly and breakup of Rodinia. Journal of the Geological Society, London, in press.

Cawood, P.A., McCausland, P.J.A. \& Dunning, G.R. 2001. Opening Iapetus: Constraints from the Laurentian margin in Newfoundland. Geological Society of America Bulletin, 113, 443-453.

Chirananda De 2003. Possible organisms similar to Ediacaran forms from the Bhander Group, Vindhyan Supergroup, Late Neoproterozoic of India. Journal of Asian Earth Sciences, 21, 387-395.

Cingolani, C. \& Dalla Sada, L. 2000. Buenos Aires cratonic region. In: Cordani, U.G.,Milani, E.J., Thomaz Filho, A. \& Campos, D.A.(eds) Tectonic evolution of South America. Rio de Janeiro: $31^{\text {st }}$ International Geological Congress, 2000, 139-150.

Cocks, L.R.M. \& Fortey, R.A. 1990. Biogeography of Ordovician and Silurian faunas. In: McKerrow, W.S. \& Scotese, C.R. (eds) Paleozoic Paleogeography and Biogeography. Geological Society of London Memoir, 12, 97-104. 
Collins, A.S. \& Buchan, C. 2004. Provenance and Age Constraints of the South Stack Group, Anglesey, UK: U-Pb SIMS Detrital Zircon Data. Journal of the Geological Society, London, 161, 743-746.

Collins, A.S.\& Windley, B.F. 2002. The Tectonic Evolution of central and northern Madagascar and its place in the Final Assembly of Gondwana. The Journal of Geology, 110, 325-340.

Collins, A.S. \& Pisarevsky, S.A. 2005. Amalgamating Eastern Gondwana: the evolution of the Circum-Indian orogens. Earth-Science Reviews, 71, 229-270.

Compston, W., Sambridge, M.S., Reinfrank, R.F., Moczydlowska, M., Vidal, G. \& Claesson, S. 1995. Numerical ages of volcanic rocks and the earliest faunal zone within the late Precambrian of east Poland. Journal of the Geological Society, London, 152, 599611.

Dada, S.S. 1998. Crust-forming ages and Proterozoic crustal evolution in Nigeria: a reappraisal of current interpretations. Journal of African Earth Sciences, 87, 65-74.

Dalziel, I.W.D. 1997. Neoproterozoic-Paleozoic geography and tectonics: review, hypothesis, environmental speculation. Geological Society of America Bulletin, 109, 1642.

Dalziel, I.W.D. 1992. On the organization of American plates in the Neoproterozoic and the breakout of Laurentia. GSA Today, 2, 237-241.

Dankers, P. \& Lapointe, P. 1981. Paleomagnetism of Lower Cambrian volcanics and a cross-cutting Cambro-Ordovician diabase dyke from Buckingham (Quebec). Canadian Journal of Earth Sciences, 18, 1174-1186. 
Deutsch, E.R. \& Rao, K.V. 1977. New palaeomagnetic evidence fails to support rotation of western Newfoundland. Nature, 266, 314-318.

De Alvarenga, C.J.S., Moura, C.A.V., Gorayeb, P.S.d.S. \& de Abreu, F.d.A.M. 2000. Paraguay and Araguaia Belts. In: Cordani, U.G., Milani, E.J., Thomaz Filho, A. \& Campos, D.A.(eds) Tectonic evolution of South America. Rio de Janeiro: $31^{\text {st }}$ International Geological Congress, 2000, 183-193.

Doig, R. \& Barton, J. M. 1968. Ages of carbonatites and other alkaline rocks in Quebec. Canadian Journal of Earth Sciences, 5, 1401-1407.

Egal, E., Guerrot, C., Le Goff, D., Thiéblemont, D. \& Chantraine, J. 1996. The Cadomian orogeny revisited in northern France. In: Nance, R.D. \& Thompson, M.D. (eds) Avalonian and Related Peri-Gondwanan Terranes of the Circum-North Atlantic. Geological Society America Special Paper, 304, 281-318.

Eguíluz, L., Gil Ibarguchi, J.I., Ábalos, B. \& Apraiz, A. 2000. Superposed Hercynian and Cadomian orogenic cycles in the Ossa-Morena zone and related areas of the Iberian Massif. Geological Society of America Bulletin, 112, 1398-1413.

Elming, S.-Å., Kravchenko, S., Khramov, A.N., Layer, P. \& Iosifidi, A.G. 2005. Paleomagnetism and 40A/39Ar age determinations of the Ediacaran traps from the southwestern margin of the East European Craton, Ukraine: relvance to the Rodinia break-up. Geophysical Research Abstracts, 7, 01467.

Embleton, B.J.J. \& Williams, G.E. 1986. Low paleolatitude of deposition for Late Precambrian periglacial varvites in South Australia: Implications for paleoclimatology. Earth and Planetary Science Letters, 79, 419-430. 
Evans, D.A.D. 2003. A fundamental Precambrian-Phanerozoic shift in earth's glacial style? Tectonophysics, 375, 353-385.

Evans, D.A.D. 2000. Stratigraphic, geochronological, and paleomagnetic constraints upon the Neoproterozoic climatic paradox. American Journal of Science, 300, 347-433.

Evans, D.A. 1998. True polar wander, a supercontinental legacy. Earth and Planetary Science Letters, 157, 1-8.

Fernández-Suárez, J., Gutiérrez-Alonso, G., Jenner, G.A. \& Tubrett, M.N. 2000. New ideas on the Proterozoic-early Palaeozoic evolution of NW Iberia; insights from U-Pb detrital zircon ages. Precambrian Research, 102, 185-206.

Fitzsimons, I.C.W. 2000. Grenville-age basement provinces in East Antarctica: Evidence for three separate collisional orogens. Geology, 28, 879-882.

Fortey, R.A. \& Cocks, L.R.M. 2003. Palaeontological evidence bearing on global Ordovician-Silurian continental reconstructions. Earth-Science Reviews, 61, 245-307.

Gallet, Y., Pavlov, V.E., Semikhatov, M.A. \& Petrov, P.Yu. 2000. Late Mesoproterozoic magnetostratigraphic results from Siberia: paleogeographic implications and magnetic field behaviour. Journal of Geophysical Research, 105, 16481-16499.

Gibbons, W. \& Horák, J.M. 1996. The evolution of the Neoproterozoic Avalonian subduction system: Evidence from the British Isles. In: Cordani, U.G.,Milani, E.J., Thomaz Filho, A. \& Campos, D.A.(eds) Tectonic evolution of South America. Rio de Janeiro: $31^{\text {st }}$ International Geological Congress, 2000, 269-280.

Gladkochub, D.P., Wingate, M.T.D., Pisarevsky, S.A., Donskaya, T.V., Mazukabzov, A.M., Ponomarchuk, V.A. \& Stanevich, A.M. 2006. Mafic intrusions in southwestern 
Siberia and implications for a Neoproterozoic connection with Laurentia. Precambrian Research, 147, 260-278.

Gorbatschev, R. \& Bogdanova, S. 1993. Frontiers in the Baltic Shield. Precambrian Research, 64, 3-21.

Goscombe, B., Gray, D.R. \& Hand, M. 2004. Variation in metamorphic style along the Northern Margin of the Damara Orogen, Namibia. Journal of Petrology, 45, 1261-1295. Greiling, R.O. \& Smith, A.G. 2000. The Dalradian of Scotland: missing link between the Vendian of northern and southern Scandinavia? Physics and Chemistry of the Earth (A), 25, 495-498.

Greiling, R.O., Jensen, S. \& Smith, A.G. 1999. Vendian-Cambrian subsidence of the passive margin of western Baltica - application of new stratigraphic data from the Scandinavian Caledonian margin. Norsk Geologisk Tidsskrift, 79, 133-144.

Grunow, A., Hanson, R. \& Wilson, T. 1996. Were aspects of Pan-African deformation linked to Iapetus opening? Geology, 24, 1063-1066.

Halliday, A. N., Graham, C. M., Aftalion, M. \& Dymoke, P. 1989. The depositional age of the Dalradian Supergroup: U-Pb and Sm-Nd isotopic studies of the Tayvallich Volcanics, Scotland. Journal of the Geological Society, London, 146, 3-6.

Hargrove, U.S., Hanson, R.E., Martin, M.W., Blenkinsop, T.G., Bowring, S.A., Walker, N. \& Munyanyiwa, H. 2003. Tectonic evolution of the Zambezi orogenic belt: geochronological, structural, and petrological constraints from northern Zimbabwe. Precambrian Research, 123, 159-186. 
Harris, L.B. \& Li, Z.X. 1995. Palaeomagnetic dating and tectonic significance of dolerite intrusions in the Albany Mobile Belt, Western Australia. Earth and Planetary Science Letters, 131, 143-164.

Hartz, E.H. \& Torsvik, T.H. 2002. Baltica upside down: a new plate tectonic model for Rodinia and the Iapetus Ocean. Geology, 30, 255-258.

Heatherington, A.L., Mueller, P.A. \& Nutman, A.P. 1996. Neoproterozoic magmatism in the Suwannee terrane: Implications for terrane correlation. In: Nance, R.D. \& Thompson, M.D. (eds) Avalonian and Related Peri-Gondwanan Terranes of the Circum-North Atlantic. Geological Society America Special Paper, 304, 257-268.

Hibbard, J. 2000. Docking Carolina: Mid-Paleozoic accretion in the southern Appalachians. Geology, 28, 127-130.

Hibbard, J.P., Stoddard, E.F., Stoddard, E.F., Secor, D.T. \& Dennis, A.J. 2002. The Carolina Zone: overview of Neoproterozoic to Early Paleozoic peri-Gondwanan terranes along the eastern flank of the southern Appalachians. Earth-Science Reviews, 57, 299339.

Higgins, M.D. \& van Breemen, O. 1998. The Age of the Sept Iles Layered Mafic Intrusion, Canada: Implications for the Late Neoproterozoic/Cambrian History of Southeastern Canada. The Journal of Geology, 106, 421-431.

Hodych, J.P., Cox, R.A. \& Košler, J. 2004. An equatorial Laurentia at 550 Ma confirmed by Grenvillian inherited zircons dated by LAM ICP-MS in the Skinner Cove volcanics of western Newfoundland: implications for inertial interchange true polar wander. Precambrian Research, 129, 93-113. 
Hoffman, P.F. 2005. Nature and origin of Neoproterozoic glacials. In: Wingate, M.T.D. \& Pisarevsky, S.A.(eds) Supercontinents and Earth Evolution Symposium 2005. Geological Society of Australia Inc. Abstracts, 81, 47-48.

Hoffman, P.F. \& Schrag, D.P. 2002. The snowball Earth hypothesis: testing the limits of global change. Terra Nova, 14, 129-155.

Iglesia Llanos, M.P., Tait, J.A., Popov, V. \& Ablamasova, A. 2005. Palaeomagnetic data from Ediacaran (Vendian) sediments of the Arkhangelsk region, NW Russia: an alternative apparent polar wander path of Baltica for the Late Proterozoic - Early Palaeozoic. Earth and Planetary Science Letters, 240, 732-747.

John, T., Schenk, V., Haase, K., Scherer \& Tempo, F. 2003. Evidence for a Neoproterozoic ocean in south-central Africa from mid-ocean-ridge-type geochemical signatures and pressure-temperature estimates of Zambian eclogites. Geology, 31, 243246.

Johnson, S.P. \& Oliver, G.J.H. 2004. Tectonothermal history of the Kaourera Arc, northern Zimbabwe: implications for the tectonic evolution of the Irumide and Zambezi Belts of south central Africa. Precambrian Research, 130, 71-97.

Johnson, S.P. \& Oliver, G.J.H. 2000. Mesoproterozoic oceanic subduction, island-arc formation and the initiation of back-arc spreading in the Kibaran Belt of central, Southern Africa; evidence from the ophiolite terrane, Chewore Inliers, northern Zimbabwe. Precambrian Research, 103, 125-146. 
Jung, S., Hoernes, S. \& Mezger, K. 2000. Geochronology and petrology of migmatites from the Proterozoic Damara Belt - importance of episodic fluid-present disequilibrium melting and consequences for granite petrology. Lithos, 51, 153-179.

Kamo, S.L. \& Gower, C.F. 1994. Note: U-Pb baddeleyite dating clarifies age of characteristic paleomagnetic remanence of Long Range dykes, southeastern Labrador. Atlantic Geology, 30, 259-262.

Kamo, S.L., Gower, C.F. \& Kroch, T.E. 1989. A birthdate for the Iapetus ocean? A precise U-Pb zircon and baddeleyite age for the Long Range dykes, S.E. Labrador. Geology, 17, 602-605.

Keppie, J.D.1993. Synthesis of Paleozoic deformational events and terrane accretion in the Canadian Appalachians. Geologische Rundschau, 82, 381-431.

Keppie, J.D. \& Ortega-Gutiérrez, F. 1999. Middle American Precambrian basement: A missing piece of the reconstructed 1-Ga orogen. In: Ramos, V.A. \& Keppie, J.D. (eds) Laurentia-Gondwana Connections Before Pangea. Geological Society of America Special Paper, 336, 199-210.

Keppie, J.D. \& Ramos, V.A. 1999. Odyssey of terranes in the Iapetus and Rheic oceans during the Paleozoic. In: Ramos, V.A. \& Keppie, J.D. (eds) Laurentia-Gondwana Connections Before Pangea. Geological Society of America Special Paper, 336, 267-276.

Keppie, J.D., Dostal, J., Nance, R.D., Miller, B.V., Ortega-Rivera, A. \& Lee, J.K.W. 2006. Circa 546 Ma plume-related dykes in the $~ 1$ Ga Novillo Gneiss (east-central Mexico): evidence for the initial separation of Avalonia. Precambrian Research, 147, 342-353. 
Keppie, J.D., Nance, R.D., Murphy, J.B. \& Dostal J. 2003. Tethyan, Mediterranean, and Pacific analogues for the Neoproterozoic-Paleozoic birth and development of periGondwanan terranes and their transfer to Laurentia and Laurussia. Tectonophysics, 365, 195-219.

Keppie, J.D., Dostal, J., Ortega-Gutiérrez, F. \& López, R. 2001. A Grenvillian arc on the margin of Amazonia: evidence from the southern Oaxacan Complex, southern Mexico. Precambrian Research, 112, 165-181.

Keppie, J.D., Nance, R.D., Murphy, J.B. \& Dostal, J. 1991. Northern Appalachians: Avalon and Meguma Terranes. In: Dallmeyer, R.D. \& Lécorché, J.P. (eds) The West African Orogens and Circum-Atlantic Correlatives. Springer-Verlag, New York, 315334.

Kirschvink, J.L. 1992. Late Proterozoic Low-Latitude Global Glaciation: The Snowball Earth. In: Schopf, J.W. \& Klein, C. (eds) The Proterozoic Biosphere. Cambridge University Press, Cambridge, 51-52.

Kirschvink, J.L. 1978. The Precambrian-Cambrian boundary problem: Paleomagnetic directions from the Amadeus basin, central Australia. Earth and Planetary Science Letters, 40, 91-100.

Kirschvink, J.L. \& Rozanov, A.Yu. 1984. Magnetostratigraphy of Lower Cambrian strata from the Siberian Platform: a palaeomagnetic pole and preliminary polarity time-scale. Geological Magazine, 121, 189-203. 
Kirschvink, J.L., Ripperdan, R.L. \& Evans, D.A.1997. Evidence for large-scale reorganization of Early Cambrian continental masses by inertial interchange true polar wander. Science, 277, 541-545.

Klootwijk, C.T. 1980. Early Palaeozoic palaeomagnetism in Australia. Tectonophysics, 64, 249-332.

Knoll, A.H.1992. The early evolution of eukaryotes, a geological perspective. Science, 256, 622-637.

Kravchinsky, V.A., Konstantinov, K.M. \& Cogne, J.P. 2001. Paleomagnetic study of Vendian and early Cambrian rocks of South Siberia and Central Mongolia: was the Siberian platform assembled at this time? Precambrian Research,110, 61-92.

Kröner, A. \& Cordani, U. 2003. African, southern Indian and South American cratons were not part of the Rodinia supercontinent: evidence from field relationships and geochronology. Tectonophysics, 375, 335-365.

Landing, E. 2005. Early Paleozoic Avalon-Gondwana unity: An obituary - Response to "Palaeontological evidence bearing on global Ordovician-Silurian continental reconstructions” by R.A. Fortey and L.R.M. Cocks. Earth-Science Reviews, 69, 169-175. Landing, E. 1996. Avalon: Insular continent by the latest Precambrian. In: Nance, R.D. \& Thompson, M.D. (eds) Avalonian and Related Peri-Gondwanan Terranes of the CircumNorth Atlantic. Geological Society of America Special Paper, 304, 29-63.

Larsen, L.M. \& Rex, D.C. 1992. A review of the 2500 Ma span of alkaline-ultramafic. Potassic and carbonatitic magmatism in West Greenland. Lithos, 28, 367-402. 
Leggo, P.M. 1974. A geochronological study of the basement complex of Uganda. Journal of the Geological Society, London, 130, 263-277.

Liégeois, J.P., Latouche, L., Boughrara, M., Navez, J. \& Guiraud, M. 2003. The LATEA metacraton (Central Hoggar, Tuareg shiled, Algeria): behaviour of an old passive margin during the Pan-African orogeny. Journal of African Earth Sciences, 37, 161-190.

Linnemann, U., Gehmlich, M., Tichomirowa, M., Buschmann, B., Nasdala, L., Jonas, P., Lützner, H. \& Bombach, K. 2000. From Cadomian subduction to Early Palaeozoic rifting: The evolution of Saxo-Thuringia at the margin of Gondwana in the light of single zircon geochronology and basin development (Central European Variscides, Germany). In: Franke, W., Altherr, R., Haak, V., Oncken, O. \& Tanner, D. (eds) Orogenic Processes-Quantification and Modelling in the Variscan Belt of Central Europe. Geological Society of London Special Publication, 179, 131-153.

Maloof, A.C., Halverson, G.P., Kirschvink, J.L., Schrag, D.P., Weiss, B.P. \& Hoffman, P.F. 2006. Combined palaeomagnetic, isotopic, and stratigraphic evidence for true polar wander from the Neoproterozoic Akademikerbreen Group, Svalbard, Norway. Geological Society of America Bulletin, 118, 1099-1124.

Martin, M.W., Grazhdankin, D.V., Bowring, S.A., Evans, D.A.D., Fedonkin, M.A. \& Kirschvink, J.L. 2000. Age of Neoproterozoic bilatarian body and trace fossils, White Sea, Russia: implications for metazoan evolution. Science, 288, 841-845.

Maslov, A.V. \& Isherskaya, M.V. 2002. Riphean sedimentary sequences of the eastern and northeastern margins of the Eastern European craton. Russian Journal of Earth Sciences, 4, 271-276. 
Maslov, A.V., Erdtmann, B.D., Ivanov, K.S., Ivanov, S.N. \& Krupenin, M.T. 1997. The main tectonic events, depositional history, and the palaeogeography of the southern Urals during the Riphean-early Palaeozoic. Tectonophysics, 276, 313-335.

Max, M.D.\& Roddick, J.C. 1989. Age of metamorphism in the Rosslare Complex, SE Ireland. Proceedings of the Geologists’s Association, 100, 113-121.

McCall, G.J.H. 2006. The Vendian (Ediacaran) in the geological record: Enigmas in geology's prelude to the Cambrian explosion. Earth-Science Reviews, 77, 1-299.

McCausland, P.J.A. \& Hodych, J.P. 1998. Palaeomagnetism of the 550 Ma Skinner Cove volcanics of western Newfoundland and opening of the Iapetus Ocean. Earth and Planetary Science Letters, 163, 15-29.

McCausland, P.J.A., Murphy, J.B. \& MacNiocaill, C. 2006. Endings and beginnings: Paleogeography of the Neoproterozoic-Cambrian transition. Precambrian Research, 147, 187-192.

McCausland, P.J.A., Van der Voo, R. D. \& Brandenburg, J.P. 2003. Preliminary paleomagnetic results from Late Neoproterozoic intrusions in Quebec, Canada: rapid apparent latitudinal motion of Laurentia. Geophysical Research Abstracts, 5, 09090. McElhinny, M.W. \& Luck, G.R. 1970. The palaeomagnetism of the Antrim Plateau Volcanics of Northern Australia. Geophysical Journal of the Royal Astronomical Society, 20, 191-205.

McElhinny, M.W., Powell, C.M. \& Pisarevsky, S.A. 2003. Paleozoic terranes of Eastern Australia and the drift history of Gondwana. Tectonophysics, 362, 41-65. 
McElhinny, M.W., Cowley, J.A. \& Edwards, D.J. 1978. Palaeomagnetism of some rocks from Peninsular India and Kashmir. Tectonophysics, 50, 41-54.

McMenamin, M.A.S. \& McMenamin, D.L. 1990. The Emergence of Animals; The Cambrian Breakthrough. Columbia University Press, New York, 217 p.

McNamara, A.K., Mac Niocaill, C., van der Pluijm, B.A. \& Van der Voo, R. 2001. West African proximity of Avalon in the latest Precambrian. Geological Society of America Bulletin, 113, 1161-1170.

McWilliams, M.O. 1981. Palaeomagnetism and Precambrian tectonic evolution of Gondwana. In: A. Kröner (ed) Precambrian Plate Tectonics. Elsevier, Amsterdam, 649687.

McWilliams, M.O. \& McElhinny, M.W. 1980. Late Precambrian paleomagnetism in Australia: The Adelaide geosyncline. The Journal of Geology, 88, 1-26.

Meert, J.G. 2003. A synopsis of events related to the assembly of eastern Gondwana. Tectonophysics, 362, 1-40.

Meert, J.G. \& Van der Voo, R. 2001. Comment on 'New palaeomagnetic result from Vendian red sediments in Cisbaikalia and the problem of the relationship of Siberia and Laurentia in the Vendian' by S. A. Pisarevsky, R. A. Komissarova and A. N. Khramov. Geophysical Journal International, 146, 867-870.

Meert, J.G. \& Van der Voo, R. 1996. Paleomagnetic and 40Ar/39Ar Study of the Sinyai Dolerite, Kenya: Implications for Gondwana Assembly. The Journal of Geology, 104, 131-142. 
Meert, J.G., Torsvik, T.H., Eide, E.A. \& Dahlgren, S. 1998. Tectonic significance of the Fen Province, S. Norway: constraints from geochronology and paleomagnetism. The Journal of Geology, 106, 553-564.

Meert, J.G., Van der Voo, R. \& Ayub, S. 1995. Paleomagnetic investigation of the Neoproterozoic Gagwe lavas and Mbozi complex, Tanzania and the assembly of Gondwana. Precambrian Research, 74, 225-244.

Meert, J.G., Van der Voo, R. \& Payne, T.W. 1994. Paleomagnetism of the Catoctin volcanic province: A new Vendian-Cambrian apparent polar wander path for North America. Journal of Geophysical Research, 99, 4625-4641.

Metelkin D.V., Belonosov I.V., Gladkochub D.P., Donskaya T.V., Mazukabzov A.M. \& Stanevich A.M. 2005. Paleomagnetic directions from Nersa intrusions of the Biryusa terrane, Siberian craton, as a reflection of tectonic events in the Neoproterozoic.

Russian Geology and Geophysics, 46, 395-410.

Moura, C.A.V. \& Gaudette, H.E. 1993. Evidence of Brasiliano/Panafrican deformation in the Araguaia belt: implication for Gondwana evolution. Revista Brasileira de Geociências, 23, 117-123.

Murphy, J.B. \& Nance, R.D. 1991. Supercontinent model for the contrasting character of Late Proterozoic orogenic belts. Geology, 19, 469-472.

Murphy, J.B. \& Nance, R.D. 1989. Model for the evolution of the Avalonian-Cadomian belt. Geology, 17, 735-738.

Murphy, J.B., Keppie, J.D., Dostal, J. \& Hynes, A.J. 1990. The geochemistry and petrology of the late Precambrian Georgeville Group: a volcanic arc-rift succession in the 
Avalon terrane of Nova Scotia. In: D’Lemos, R.S., Strachan, R.A. \& Topley, C.G. (eds.)

The Cadomian Orogeny. Geological Society of London Special Publication, 51, 383-393.

Murphy, J.B., Pisarevsky, S.A., Nance, R.D. \& Keppie, J.D. 2004. Neoproterozoic - early Paleozoic evolution of peri-Gondwanan terranes: implications for Laurentia-Gondwana connections. International Journal of Earth Sciences, 93, 659-692.

Murphy, J.B., Eguiluz, L. \& Zulauf, G. 2002. Cadomian orogens, peri-Gondwanan correlatives and Laurentia-Baltica connections. Tectonophysics, 352, 1-9.

Murphy, J.B., Strachan, R.A., Nance, R.D., Parker, K.D. \& Fowler, M.B. 2000. ProtoAvalonia: a 1.2-1.0 Ga tectonothermal event and constraints for the evolution of Rodinia. Geology, 28, 1071-1074.

Murphy, J.B., Keppie, J.D., Dostal, J. \& Nance, R.D. 1999. Neoproterozoic-early Paleozoic evolution of Avalonia. In: Ramos, V.A. \& Keppie, J.D. (eds) LaurentiaGondwana Connections Before Pangea. Geological Society of America Special Paper, 336, 253-266.

Murphy, J.B., Gutiérrez-Alonso, G., Nance, R.D., Fernández-Suárez, J., Keppie, J.D., Quesada, C., Strachan, R.A. \& Dostal J. 2006. Origin of the Rheic Ocean: Rifting along a Neproterozoic suture? Geology, 34, 325-328.

Murthy, G., Gower, C., Tubrett, M. \& Pätzold, R. 1992. Paleomagnetism of Eocambrian Long Range dykes and Double Mer Formation from Labrador, Canada. Canadian Journal of Earth Sciences, 29, 1224-1234.

Nance, R.D. \& Murphy, J.B. 1990. Kinematic history of the Bass River Complex, Nova Scotia: Cadomian tectonostratigraphic relations in the Avalon terrane of the Canadian 
Appalachians. In: D'Lemos, R.S., Strachan, R.A. \& Topley, C.G. (eds.) The Cadomian Orogeny. Geological Society of London Special Publication, 51, 395-406.

Nance, R.D. \& Murphy, J.B.1994. Contrasting basement isotopic signatures and the palinspastic restoration of peripheral orogens: Example from the Neoproterozoic Avalonian-Cadomian belt. Geology, 22, 617-620.

Nance, R.D., Murphy, J.B. \& Keppie, J.D. 2002. Cordilleran model for the evolution of Avalonia. Tectonophysics, 352, 11-32.

Nance, R. D., Murphy, J. B., Strachan, R. A., D’Lemos, R. S. \& Taylor, G. K. 1991. Late Proterozoic tectonostratigraphic evolution of the Avalonian and Cadomian terranes. Precambrian Research, 53, 41-78.

Nawrocki, J., Boguckij, A. \& Katinas, V. 2004. New late Vendian palaeogeography of Baltica and TESZ. Geological Quarterly, 48, 309-316.

Neubauer, F. 2002. Evolution of late Neoproterozoic to early Paleozoic tectonic elements in Central and Southeast European Alpine mountain belts: review and synthesis. Tectonophysics, 352, 87-103.

Nikishin, A.M., Ziegler, P.A., Stephenson, R.A., Cloetingh, S.A.P.L., Furne, A.V., Fokin, P.A., Ershov, A.V., Bolotov, S.N., Korotaev, M.V., Alekseev, A.S., Gorbachev, V.I., Shipilov, E.V., Lankreijer, A., Bembinova, E.Yu. \& Shalimov, I.V. 1996. Late Precambrian to Triassic history of the East European Craton: dynamics of sedimentary basin evolution. Tectonophysics, 268, 23-63.

O’Brien, S.J., Wardle, R.J. \& King, A.F.1983. The Avalon zone: a Pan-African terrane in the Appalachian orogen of Canada. Geological Journal, 18, 195-222. 
Oliver, G.J.H., Johnson, S.P., Williams, I.S. \& Herd, D.A. 1998. Relic 1.4 Ga oceanic crust in the Zambezi Valley, northern Zimbabwe; evidence for Mosoproterozoic supercontinental fragmentation. Geology, 26, 571-573.

Olovyanishnikov, V.G., Roberts, D. \& Siedlecka, A. 2000. Tectonics and sedimentation of the Meso- to Neoproterozoic Timan-Varanger belt along the northeastern margin of Baltica. Polarforschung, 68, 267-274.

Omarini, R.H., Sureda, R.J., Götze, H.-J., Seilacher, A. \& Pflüger, F. 1999. Puncoviscana folded belt in northwestern Argentina: testimony of Late Proterozoic Rodinia fragmentation and pre-Gondwana collisional episodes. International Journal of Earth Sciences, 88, 76-97.

Onstott, T.C. \& Hargraves, R.B. 1981. Proterozoic transcurrent tectonics: palaeomagnetic evidence from Venezuela and Africa. Nature, 289, 131-136.

Ortega-Obregon, C., Keppie, J.D., Solari, L.A., Ortega-Gutiérrez, F., Dostal, J., Lopez, R., Ortega-Rivera, A. \& Lee, J.W.K. 2003. Geochronology and geochemistry of the $~ 917$ Ma, calc-alkaline Etla granitoid pluton (Oaxaca, southern Mexico): evidence of postGrenvillian subduction along the northern margin of Amazonia. International Geology Review, 45, 596-622.

Pavlov, V.E., Gallet, Y., Petrov, P.Yu., Zhuravlev, D.Z. \& Shatsillo, A.V. 2002. Uy series and late Riphean sills of the Uchur-Maya area: isotopic and palaeomagnetic data and the problem of the Rodinia supercontinent. Geotectonics, 36, 278-292. 
Pavlov, V.E., Gallet, Y. \& Shatsillo, A.V. 2000. Palaeomagnetism of the upper Riphean Lakhanda Group of the Uchur-Maya area and the hypothesis of the late Proterozoic supercontinent. Izvestiya, Physics of the Solid Earth, 36, 638-648.

Pimentel, M.M., Fuck, R.A., Jost, H., Ferreira Filho, C.F. \& Araújo, S.M. 2000. Geology of the central part of the Tocantins Province: implications for the geodynamic history of the Brasília belt. In: Cordani, U.G., Milani, E.J., Thomaz Filho, A. \& Campos, D.A.(eds) Tectonic evolution of South America. Rio de Janeiro: $31^{\text {st }}$ International Geological Congress, 2000, 195-229.

Pimentel, M.M., Fuck, R.A. \& Botelho, N.F. 1999. Granites and the geodynamic history of the Neoproterozoic Brazilia belt, Central Brazil: a review. Lithos, 46, 463-483.

Pimentel, M.M., Heaman, L.M. \& Fuck, R.A. 1991. U-Pb zircon and sphene geochronology of late Proterozoic volcanic arc rock unis from southwestern Goiás, central Brazil. Journal of South American Earth Sciences, 4, 329-339.

Pin, C. \& Poidevin, J.L. 1987. U-Pb zircon evidence for a Pan-African granulite facies metamorphism in the Central African Republic. A new interpretation of the high-grade series of the northern border of the Congo Craton. Precambrian Research, 36, 303-312.

Piper, J.D.A. 2000. The Neoproteroozic Supercontinent: Rodinia or Palaeopangea? Earth and Planetary Science Letters, 176, 131-146.

Pisarevsky, S.A. 2005. New edition of the Global Paleomagnetic Database. EOS transactions, 86(17), 170.

Pisarevsky, S.A. 2001. Palaeomagnetic study of Vines 1. Geological Survey of Western Australia, Record 2001/18, Appendix 4. 
Pisarevsky, S.A. \& Natapov, L.M. 2003. Siberia and Rodinia. Tectonophysics, 375, 221245.

Pisarevsky, S.A., Wingate, M.T.D., Stevens, M.K. \& Haines, P.W. 2007. Paleomagnetic results from the Lancer-1 stratigraphic drill hole, Officer Basin, Western Australia, and implications for Rodinia reconstructions. Australian Journal of Earth Sciences, in press.

Pisarevsky, S.A., Wingate, M.T.D., Powell, C.McA., Johnson, S. \& Evans, D.A.D. 2003. Models of Rodinia assembly and fragmentation. In: Yoshida, M., Windley, B., Dasgupta, S. (eds) Proterozoic East Gondwana: supercontinent assembly and breakup. Geological Society, London, Special Publication, 206, 35-55.

Pisarevsky, S.A., Komissarova, R.A. \& Khramov, A.N. 2001a. Reply to comment by J. G. Meert and R. Van der Voo on 'New palaeomagnetic result from Vendian red sediments in Cisbaikalia and the problem of the relationship of Siberia and Laurentia in the Vendian'. Geophysical Journal International, 146, 871-873.

Pisarevsky, S.A., Li, Z.X., Grey, K. \& Stevens, M.K. 2001b. A palaeomagnetic study of Empress 1A, a stratigraphic drillhole in the Officer Basin: new evidence for the lowlatitude position of Australia in the Neoproterozoic. Precambrian Research, 110, 93-108. Pisarevsky, S.A., Komissarova, R.A. \& Khramov, A.N. 2000. New palaeomagnetic result from Vendian red sediments in Cisbaikalia and the problem of the relationship of Siberia and Laurentia in the Vendian. Geophysical Journal International, 140, 598-610.

Pisarevsky, S.A., Gurevich, E.L. \& Khramov, A.N.1997. Palaeomagnetism of the Lower Cambrian sediments from the Olenek river section (northern Siberia): paleopoles and a 
problem of magnetic polarity in Early Cambrian. Geophysical Journal International, 130, 746-756.

Poorter, R.P.E. 1972. Palaeomagnetism of the Rogaland Precambrian (southwestern Norway). Physics of the Earth and Planetary Interiors, 5, 167-176.

Popov, V., Khramov, A. \& Bachtadse, V. 2005. Palaeomagnetism, magnetic stratigraphy, and petromagnetism of the Upper Vendian sedimentary rocks in the sections of the Zolotitsa River and in the Verkhotina Hole, Winter Coast of the White Sea, Russia. Russian Journal of Earth Sciences, 7(2), 1-29.

Popov, V., Iosifidi, A., Khramov, A., Tait, J. \& Bachtadse, V. 2002. Paleomagnetism of Upper Vendian sediments from the Winter Coast, White Sea region, Russia: implications for the paleogeography of Baltica during Neoproterozoic times. Journal of the Geophysical Research, 107 (B11, 2315), doi: 10.1029/2001JB001607.

Poprawa, P., Sliaupa, S., Stephenson, R. \& Lazauskiene, J.1999. Late Vendian-Early Palaeozoic tectonic evolution of the Baltic Basin: regional tectonic implications from subsidence analysis. Tectonophysics, 314, 219-239.

Powell, C.McA. \& Pisarevsky, S.A. 2002. Late Neoproterozoic assembly of East Gondwanaland. Geology, 30, 3-6.

Prave, A.R. 1996. Tale of three cratons: Tectonostratigraphic anatomy of the Damara orogen in northwestern Nanibia and the assembly of Gondwana. Geology, 24, 1115-1118. Puchkov, V.N.(ed) 2003. Magmatism on passive margins of the Rodinia. Materials of the international conference. Ufa, Geological Institute of the USC RAS, 40 p. 
Puffer, J.H. 2002. A Late Neoproterozoic eastern Laurentian superplume: location, size, chemical composition, and environmental impact. American Journal of Science, 302, 127.

Quesada, C. 1990. Precambrian terranes in the Iberian Variscan foldbelt. In: Strachan, R.A. \& Taylor, G.K. (eds) Avalonian and Cadomian Geology of the North Atlantic. Blackie, London, 109-133.

Ramos, V.A. 1988. Late Proterozoic - Early Paleozoic of South America - a collisional history. Episodes, 11, 168-174.

Rapalini, A.E. 2006. New late Proterozoic paleomagnetic pole for the Rio de la Plata craton: Implications for Gondwana. Precambrian Research, 147, 223-233.

Rapela, C.W., Fanning, C.M. \& Pankhurst, R.J. 2005. The Rio de la Plata Craton: the search for its full extent. In: Pankhurst, R.J. and Veiga, C.D. (eds), Gondwana 12: Geological and Biological Heritage of Gondwana, Abstracts, Academia Nacional de Ciencias, Cordoba, Argentina, p.

Roberts, D. \& Siedlecka, A. 2002. Timanian orogenic deformation along the northeastern margin of Baltica, northwest Russia and northeast Norway, and Avalonian-Cadomian connections. Tectonophysics, 352, 169-184.

Roberts, R.J., Corfu, F., Torsvik, T.H., Ramsay, D.M. \& Ashwal, L.D. 2004. Redefining the magmatic evolution of the Kalak Nappe Complex. The $26^{\text {th }}$ Nordic Geological Winter Meeting. Geologiska Föreningens I Stockholm Förhandlingar, 126, 84.

Ruiz, J., Tosdal, R.M., Restrepo, P.A. \& Murillo-Muñetón, G. 1999. Pb isotope evidence for Columbia-southern Mexico connections in the Proterozoic. In: Ramos, V.A. \& 
Keppie, J.D. (eds) Laurentia-Gondwana Connections Before Pangea. Geological Society of America Special Paper, 336, 183-197.

Sánchez-Bettucci, L. \& Rapalini, A.E. 2002. Paleomagnetism of the Sierra de Las Animas Complex, southern Uruguay: its implications in the assembly of western Gondwana. Precambrian Research, 118, 243-265.

Schmidt, P.W. \& Williams, G.E. 1996. Palaeomagnetism of the ejecta-bearing Bunyeroo Formation, late Neoproterozoic, Adelaide fold belt, and the age of the Acraman impact. Earth and Planetary Science Letters, 144, 347-357.

Schmidt, P.W. \& Williams, G.E.1995. The Neoproterozoic climatic paradox: Equatorial palaeolatitude for Marinoan glaciation near sea level in South Australia. Earth and Planetary Science Letters, 134, 107-124.

Schmidt, P.W., Williams, G.E. \& Embleton, B.J.J. 1991. Low palaeolatitude of Late Proterozoic glaciation: Early timing of remanence in haematite of the Elatina Formation, South Australia. Earth and Planetary Science Letters, 105, 355-367.

Shumlyanskyy, L. \& Andréasson, P.G. 2004. New geochemical and geochronological data from the Volyn Flood Basalt in Ukraine and correlation with large igneous events in Baltoscandia. The 26th Nordic Geological Winter Meeting. Geologiska Föreningens I Stockholm Förhandlingar, 126, 85-86.

Siedlecka, A., Roberts, D., Nystuen, J.P. \& Olovyanishnikov, V.G. 2004. Northeastern and northwestern margins of Baltica in Neoporteroozic time: evidence from the Timanian and Caledonian Orogens. In: Gee, D.G. \& Pease, V.L. (eds) The Neoproterozoic Timanide Orogen of Eastern Baltica. Geological Society, London, Memoirs, 30,169-190. 
Smethurst, M.A., Khramov, A.N. \& Torsvik, T.H. 1998. The Neoproterozoic and Palaeozoic palaeomagnetic data for the Siberian Platform: from Rodinia to Pangea, Earth-Science Reviews, 43, 1-24.

Sohl, L.E., Christie-Blick, N. \& Kent, D.V. 1999. Paleomagnetic polarity reversals in Marinoan (ca. $600 \mathrm{Ma}$ ) glacial deposits of Australia: Implications for the duration of lowlatitude glaciation in Neoproterozoic time. Geological Society of America Bulletin, 111, 1120-1139.

Solari, L.A., Keppie, J.D., Ortega-Gutiérrez, F., Cameron, K.L., Lopez, R. \& Hames, W.E. 2003. 990 and 1100 Ma Grenvillian tectonothermal events in the northern Oaxacan Complex, southern Mexico: roots of an orogen. Tectonophysics, 365, 257-282.

Storetvedt, K.M.1966. Remanent magnetization of some dolerite intrusions in the Egersund area, southern Norway. Geophysica Norvegica, 26, 17 p.

Strachan, R.A., Nance, R.D., Dallmeyer, R.D., D’Lemos, R.S., Murphy, J.B. \& Watts, G.R. 1996. Late Precambrian tectonothermal evolution of the Malverns Complex. Journal of the Geological Society, London, 153, 589-600.

Stukas, V. \& Reynolds, P.H. 1974. 40Ar/39Ar dating of the Long Range dikes, Newfoundland. Earth and Planetary Science Letters, 22, 256-266.

Symons, D.T.A. \& Chiasson, A.D. 1991. Paleomagnetism of the Callander Complex and the Cambrian apparent polar wander path for North America. Canadian Journal of Earth Sciences, 28, 355-363. 
Tanczyk, E.I., Lapointe, P., Morris, W.A. \& Schmidt, P.W. 1987. A paleomagnetic study of the layered mafic intrusion at Sept-Iles, Quebec. Canadian Journal of Earth Science, 24, 1431-1438.

Theokritoff, G. 1979. Early Cambrian provincialism and biogeographic boundaries in the North Atlantic region. Lethaia, 12, 281-295.

Thomas, W,A 2005. Tectonic inheritance at a continental margin. GSA Today, 16(2), 411.

Tohver, E., D’Agrella-Filho, M.S. \& Trindade, R.I.F. 2006. Paleomagnetic record of Africa and South America for the 1200-500 Ma interval, and evaluation of Rodinia and Gondwana assemblies. Precambrian Research, 147, 193-222.

Torsvik, T.H. \& Rehnström, E.F. 2001. Cambrian palaeomagnetic data from Baltica: implications for true polar wander and Cambrian palaeogeography. Journal of the Geological Society, London, 158, 321-329.

Torsvik, T.H., Carter, L.M., Ashwal, L.D., Bhushan, S.K., Pandit, M.K. \& Jamtveit, B., 2001. Rodinia refined or obscured: palaeomagnetism of the Malani igneous suite (NW India). Precambrian Research, 108, 319-333.

Trindade, R.I.F., D’Agrella-Filho, M.S., Epof, I. \& Brito Neves, B.B. 2006.

Paleomagnetism of Early Cambrian Itabaiana mafic dikes (NE Brazil) and the final assembly of Gondwana. Earth and Planetary Science Letters, 244, 361-367.

Trindade,R.I.F., Font,E., D’Agrella-Filho,M.S., Nogueira,A.C.R. \& Riccomini,C. 2003. Low-latitude and multiple geomagnetic reversals in the Neoproterozoic Puga cap carbonate, Amazon craton. Terra Nova, 15, 441-446. 
Trompette, R.1994. Geology of Western Gondwana (2000 - 500 Ma). A.A. Balkema, Rotterdam/Brookfield, 350 p.

Trompette, R. 1997. Neoproterozoic ( 600 Ma) aggregation of Western Gondwana: a tentative scenario. Precambrian Research, 82, 101-112.

Tucker, R.D. \& Pharoah, T.C. 1991. U-Pb zircon ages of late Precambrian rocks in southern Britain. Journal of the Geological Society, London, 148, 435-443.

Valeriano, C.M., Machado, N., Simonetti, A., Valladares, C.S., Seer, H.J. \& Simões, L.S.A. 2004. U-Pb geochronology of the southern Brazília belt (SE-Brazil): sedimentary provenance, Neoproterozoic orogeny and assembly of West Gondwana. Precambrian Research, 130, 27-55.

Van Alstine, D.R. \& Gillett, S.L.1979. Paleomagnetism of Upper Precambrian sedimentary rocks from the Desert Range, Nevada. Journal of Geophysical Research, 84, 4490-4500.

Van der Voo, R. 1990. The reliability of paleomagnetic data. Tectonophysics, 184, 1-9. Van der Voo, R.1988. Paleozoic paleogeography of North America, Gondwana, and intervening displaced terranes: comparisons of paleomagnetism with paleoclimatology and biogeographical patterns. Geological Society of America Bulletin, 100, 311-324.

Vinyu, M.L., Hanson, R.E., Martin, M.W., Bowring, S.A., Jelsma, H.A., Krol, M.A. \& Dirks, P.H.G.M. 1999. U/Pb and 40Ar/39Ar geochronological constraints on the tectonic evolution of the easternmost part of the Zambezi orogenic belt, northeast Zimbabwe. Precambrian Research, 98, 67-82. 
von Raumer, J.F., Stampfli, G.M., Borel, G. \& Bussy, F. 2002. Organization of preVariscan basement areas at the north-Gondwanan margin. International Journal of Earth Sciences, 91, 35-52.

Walderhaug, H.J., Torsvik, T.H., Eide, E.A. \& Meert, J.G. 2003. Magnetic properties and age of the Alnø Carbonatite Complex (Sweden). Geophysical Research Abstracts, 5, 10358.

Williams, H. \& Hiscott, R.N. 1987. Definition of the Iapetus rift-drift transition in western Newfoundland. Geology, 15, 1044-1047.

Willner, A.P., Sindern, S., Metzger, R., Ermolaeva, T., Kramm, U., Puchkov, V. \& Kronz, A. 2003. Typology and single grain U/Pb ages of detrital zircons from Proterozoic sandstones in the SW Urals (Russia): early time marks at the eastern margin of Baltica. Precambrian Research, 124, 1-20.

Willner, A.P., Ermolaeva, T., Stroink, L., Glasmacher, U.A., Giese, U., Puchkov, V.N., Kozlov, V.I. \& Walter, R. 2001. Contrasting provenance signals in Riphean and Vendian sandstones in the SW Urals (Russia): constraints for a change from passive to active continental margin conditions in the Neoproterozoic. Precambrian Research, 110, 215239.

Wingate, M.T.D. \& Giddings, J.W. 2000. Age and palaeomagnetism of the Mundine Well dyke swarm, Western Australia: implications for an Australia-Laurentia connection at 755 Ma. Precambrian Research, 100, 335-357. 
Wingate, M.T.D., Pisarevsky, S.A. \& de Waele, B. 2004. Paleomagnetism of the 765 Ma Luakela Volcanics in NW Zambia and Implications for Neoproterozoic Positions of the Congo Craton. AGU Fall Meeting Supplement, Abstract U32A-03.

Zulauf, G., Schitter, F., Riegler, G., Finger, F., Fiala, J. \& Vejnar, Z. 1999. Age constraints on the Cadomian evolution of the Teplá-Barrandian unit (Bohemian Massif) through electron microprobe dating of metamorphic monazite. Zeitschrift der Deutschen Geologischen Gesellschaft, 150/4, 627-639. 